\title{
Fate of terrigenous organic matter across the Laptev Sea from the mouth of the Lena River to the deep sea of the Arctic interior
}

\author{
Lisa Bröder ${ }^{1,2}$, Tommaso Tesi ${ }^{1,2,3}$, Joan A. Salvadón ${ }^{1,2}$, Igor P. Semiletov ${ }^{4,5,6}$, Oleg V. Dudarev $^{5,6}$, and \\ Örjan Gustafsson ${ }^{1,2}$ \\ ${ }^{1}$ Department of Environmental Science and Analytical Chemistry, Stockholm University, Stockholm, Sweden \\ ${ }^{2}$ Bolin Centre for Climate Research, Stockholm University, Stockholm, Sweden \\ ${ }^{3}$ Institute of Marine Sciences - National Research Council, Bologna, Italy \\ ${ }^{4}$ International Arctic Research Center, University Alaska Fairbanks, Fairbanks, USA \\ ${ }^{5}$ Pacific Oceanological Institute, Russian Academy of Sciences, Vladivostok, Russia \\ ${ }^{6}$ Tomsk National Research Politechnical University, Tomsk, Russia \\ Correspondence to: Lisa Bröder (lisa.broder@aces.su.se)
}

Received: 25 April 2016 - Published in Biogeosciences Discuss.: 18 May 2016

Revised: 26 August 2016 - Accepted: 30 August 2016 - Published: 9 September 2016

\begin{abstract}
Ongoing global warming in high latitudes may cause an increasing supply of permafrost-derived organic carbon through both river discharge and coastal erosion to the Arctic shelves. Mobilized permafrost carbon can be either buried in sediments, transported to the deep sea or degraded to $\mathrm{CO}_{2}$ and outgassed, potentially constituting a positive feedback to climate change.

This study aims to assess the fate of terrigenous organic carbon (TerrOC) in the Arctic marine environment by exploring how it changes in concentration, composition and degradation status across the wide Laptev Sea shelf. We analyzed a suite of terrestrial biomarkers as well as source-diagnostic bulk carbon isotopes $\left(\delta^{13} \mathrm{C}, \Delta^{14} \mathrm{C}\right)$ in surface sediments from a Laptev Sea transect spanning more than $800 \mathrm{~km}$ from the Lena River mouth ( $<10 \mathrm{~m}$ water depth) across the shelf to the slope and rise (2000-3000 m water depth). These data provide a broad view on different TerrOC pools and their behavior during cross-shelf transport. The concentrations of lignin phenols, cutin acids and high-molecular-weight (HMW) wax lipids (tracers of vascular plants) decrease by 89-99\% along the transect. Molecular-based degradation proxies for TerrOC (e.g., the carbon preference index of HMW lipids, the HMW acids / alkanes ratio and the acid / aldehyde ratio of lignin phenols) display a trend to more degraded TerrOC with increasing distance from the coast. We infer that the degree of degradation of permafrost-derived TerrOC is a function of the time spent under oxic conditions during protracted cross-
\end{abstract}

shelf transport. Future work should therefore seek to constrain cross-shelf transport times in order to compute a TerrOC degradation rate and thereby help to quantify potential carbon-climate feedbacks.

\section{Introduction}

Amplified global warming in high latitudes has raised growing concern about potential positive carbon-climate feedbacks. Arctic soils store about half of the global soil organic carbon (Tarnocai et al., 2009), with $60 \%$ of this in perennially frozen grounds (Hugelius et al., 2014). With ongoing climate change these vast carbon reservoirs become increasingly vulnerable. Mobilization and transport of old terrigenous organic carbon (TerrOC) into the Arctic Ocean are expected to intensify (Gustafsson et al., 2011) through enhancing river discharge (McClelland et al., 2008) with augmenting sediment loads (Gordeev, 2006; Syvitski, 2002) and accelerating coastal erosion (Günther et al., 2013). This material can be buried in the sediments of the Arctic shelves, transported across the margin towards deeper basins or degraded and re-introduced into the modern carbon cycle as $\mathrm{CO}_{2}$, thereby not only providing a potential positive feedback to global warming but also causing severe ocean acidification (Semiletov et al., 2016). The fate of permafrostreleased TerrOC in the marine environment is thus crucial 
for future climate projections, yet insufficiently understood (Vonk and Gustafsson, 2013).

The East Siberian Arctic Shelf (ESAS) is with a width of $>800 \mathrm{~km}$ the world's largest continental shelf. It receives TerrOC both from the erosion of the East Siberian shoreline, largely consisting of organic-rich, late Pleistocene icecomplex deposits (Yedoma), and via the great Russian arctic rivers (Ob, Yenisei, Lena, Indigirka and Kolyma) which drain extensive areas of continuous and discontinuous permafrost. The Laptev Sea is a representative for the TerrOC-dominated Siberian shelf seas, since its main organic carbon input originates from substantial coastal erosion (as observed in the Buor-Khaya Bay; Sánchez-García et al., 2011; Semiletov et al., 2011; Vonk et al., 2012) and the Lena River, the main fluvial sediment source for the entire ESAS (Holmes et al., 2002).

Previous studies have focused on near-shore areas and the inner shelf (e.g., Bröder et al., 2016; Charkin et al., 2011; Feng et al., 2015; Karlsson et al., 2011; Salvadó et al., 2015; Sánchez-García et al., 2011; Semiletov et al., 2005, 2012, 2013; Tesi et al., 2014; Vonk et al., 2010, 2012, 2014; Winterfeld et al., 2015a, b). They reported large fractions of old TerrOC in particulate organic carbon (POC) and surface sediments close to the coast, using different approaches such as applying carbon-isotope-based source apportionment (e.g., Gustafsson et al., 2011; Semiletov et al., 2005; Vonk et al., 2010, 2012, 2014; Salvadó et al., 2015, for the ironassociated OC fraction in the sediment) and by analyzing terrestrial biomarkers in both surface sediments (e.g., Feng et al., 2013; Stein and Macdonald, 2004; Tesi et al., 2014, 2016) and POC in the water column (e.g., Charkin et al., 2011; Karlsson et al., 2011; Winterfeld et al., 2015a). This is the first study that encompasses sampling stations along the entire transect from the Lena River mouth, across the wide Laptev Sea shelf, to the continental slope and rise. Our major objective was to gain new insights regarding the behavior of different TerrOC pools, in particular investigating potential degradation of permafrost-released material along the landshelf-basin continuum. The Laptev Sea and adjacent East Siberian Sea are among the widest continental margins on Earth (Jakobsson et al., 2004). Protracted cross-shelf transport may hence result in long oxygen exposure times (OETs), which might exert first-order control on TerrOC degradation (e.g., Keil et al., 2004). Our study area is thus well suited to test hypotheses on the fate of permafrost carbon in terms of carbon-climate feedback. We have therefore characterized TerrOC in surface sediments along the Laptev Sea transect on both bulk and molecular level, exploiting source-diagnostic bulk carbon isotopes $\left(\delta^{13} \mathrm{C}, \Delta^{14} \mathrm{C}\right)$ as well as an extensive biomarker suite (lignin phenols and cutin acids obtained by alkaline $\mathrm{CuO}$ oxidation and high-molecular-weight (HMW) solvent-extractable lipids, such as $n$-alkanes and $n$-alkanoic acids).

\section{Material and methods}

\subsection{Study area}

The Laptev Sea is the shallowest of the Arctic shelf seas with an average depth of $48 \mathrm{~m}$ (Jakobsson et al., 2004). It spans over $498000 \mathrm{~km}^{2}$ with a volume of $24000 \mathrm{~km}^{3}$ and is located between the Kara Sea and Severnaya Zemlya in the west and the East Siberian Sea and the New Siberian Islands in the east (Fig. 1). The main sources of POC for the Laptev Sea are terrigenous, both from coastal erosion and river runoff (Sánchez-García et al., 2011; Stein and Macdonald, 2004). Marine primary production is limited to on average 2 ice-free months per year and therefore generally low. Nutrient-poor waters on the Siberian shelves resulting from a strong stratification further impede phytoplankton growth (Sakshaug, 2004).

The destabilization of Pleistocene ice-complex deposits along the coastline is a main sediment source for the Laptev Sea (Rachold et al., 2000). The total POC input from coastal erosion to Laptev and East Siberian Sea is estimated to be between 4.0 $\mathrm{Tg} \mathrm{yr}^{-1}$ (Semiletov, 1999; Stein and Fahl, 2000) and $22 \pm 8 \mathrm{Tg} \mathrm{yr}^{-1}$ (including net sub-sea permafrostcarbon erosion; Vonk et al., 2012).

The Lena River is estimated to provide $20.7 \mathrm{Tg}$ of sediment per year (Holmes et al., 2002), i.e., $>70 \%$ of the total riverine input to the Laptev Sea (Gordeev, 2006) with an average water discharge of $588 \mathrm{~km}^{3} \mathrm{yr}^{-1}$ (Holmes et al., 2012). It drains a watershed of $\sim 2.46 \times 10^{6} \mathrm{~km}^{2}$ (Holmes et al., 2012), of which $77 \%$ is underlain by continuous permafrost (Amon et al., 2012). Water discharge peaks in June, during the spring flood, when about $75 \%$ of total organic carbon (TOC) is delivered (Rachold et al., 2004). Total POC discharge by the Lena River can be up to $0.38 \mathrm{Tg} \mathrm{yr}^{-1}$ (Semiletov et al., 2011).

Sediment transport pathways are largely influenced by the prevailing atmospheric conditions: during cyclonic summers (i.e., positive phase of the Arctic Oscillation), northerly winds predominate, strengthening the Siberian Coastal Current, which transports Lena River water masses along the coast towards the East Siberian Sea; in contrast, during anticyclonic summers (i.e., negative phase of the Arctic Oscillation and mainly southerly winds) the Lena River plume is exported onto the mid-shelf and towards the deep part of the Arctic Ocean (Charkin et al., 2011; Dmitrenko et al., 2008; Guay et al., 2001; Wegner et al., 2013; Weingartner et al., 1999). Sediment transport in the Laptev Sea is strongly seasonal. The main transport of Lena River water with high concentrations of suspended particulate matter (SPM) towards the mid-shelf takes place shortly after riverice breakup (Wegner et al., 2005). During the ice-free summer, SPM circulates between inner and mid-shelf with very little material escaping over the shelf break to the deeper parts of the Arctic Ocean. Significant sediment export is suggested to happen during freeze-up through SPM that is incor- 


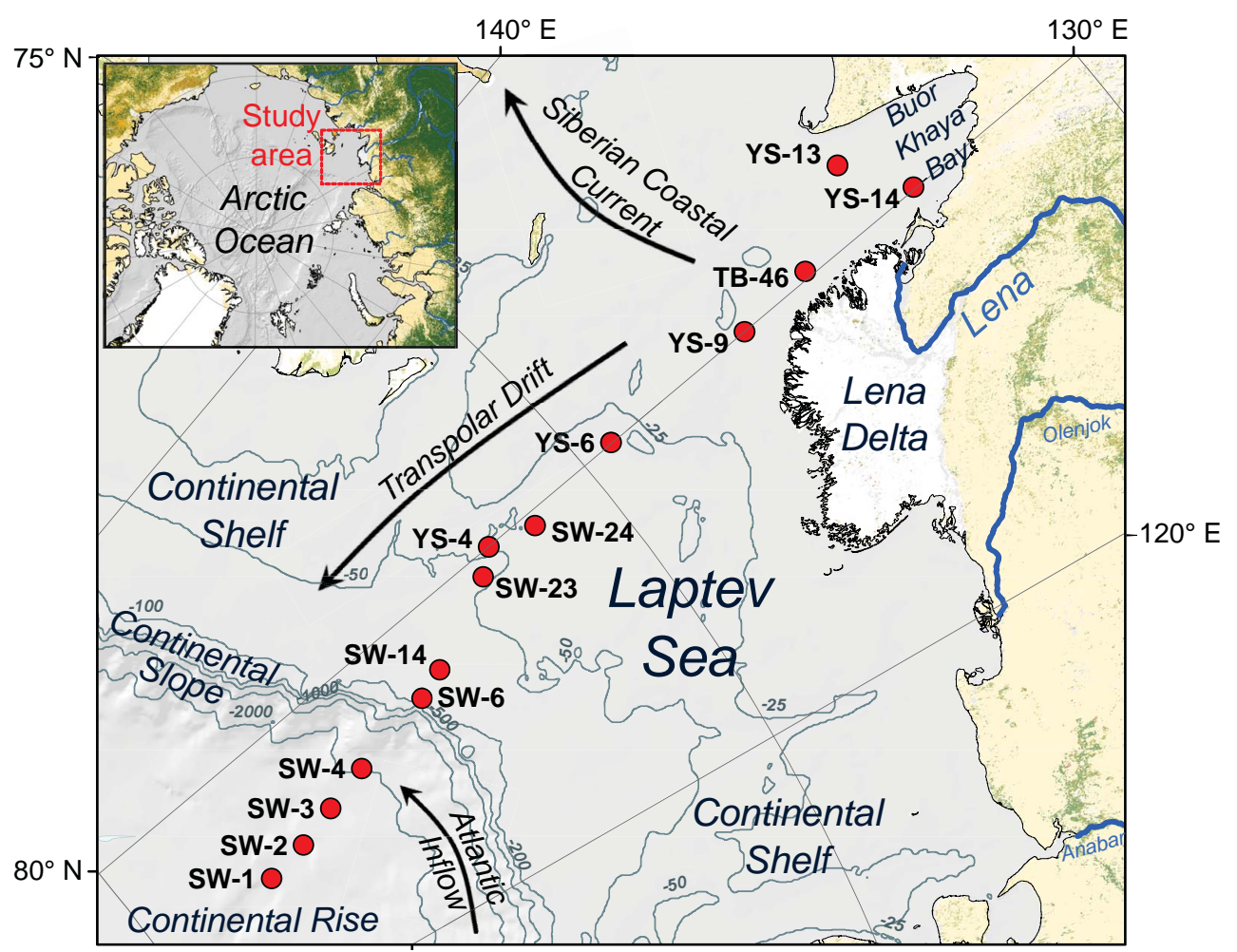

Figure 1. Map of the study area in the Laptev Sea. Red filled circles mark the sediment sampling sites. The transect reaches from the Lena River mouth and the Buor-Khaya Bay (water depths $\sim 10 \mathrm{~m}$ ) across the Laptev Sea Shelf (mean depth $\sim 50 \mathrm{~m}$ ) to the slope/shelf break and rise (water depths $\sim 3000 \mathrm{~m}$ ). Arrows show the directions of the prevailing ocean currents.

porated in sea ice and then transported across the continental margin (Dethleff, 2005; Eicken et al., 1997) or through the formation of dense bottom water resulting from brine ejection (Dethleff, 2010; Ivanov and Golovin, 2007). Hardly any sediment transport occurs beneath the ice cover.

Holocene-scale linear sedimentation rates for the Laptev Sea vary between 0.12 and $0.59 \mathrm{~mm} \mathrm{yr}^{-1}$ according to ${ }^{14} \mathrm{C}$ dating of marine bivalves (Stein and Fahl, 2004, and references therein), whereas centennial-scale ${ }^{210} \mathrm{~Pb}$-derived rates for the more recent Laptev Sea can be up to $1.3 \mathrm{~mm} \mathrm{yr}^{-1}$ (Vonk et al., 2012). These rates do not seem to be correlated with water depth on the shelf, but values for the continental slope and rise tend to be on the lower end $\left(0.12-0.38 \mathrm{~mm} \mathrm{yr}^{-1}\right.$ ) (Stein and Fahl, 2004, and references therein).

\subsection{Sampling}

Sediment sampling locations span from close to the Lena River mouth and in the Buor-Khaya Bay, across the shelf, to the continental slope and rise, covering a transect of $>800 \mathrm{~km}$ with water depths increasing by more than 2 orders of magnitude (Fig. 1). Samples SW-1, SW-2, SW-3, SW-4, SW-6, SW14, SW-23 and SW-24 were collected during the SWERUSC3 expedition on IB ODEN during summer 2014 using an Oktopus multicorer (eight Plexiglas tubes, $10 \mathrm{~cm}$ diameter).
All other samples were collected during the International Siberian Shelf Study (ISSS-08) expedition onboard the R/V Yacob Smirnitskyi during summer 2008. The YS-4, YS-6, YS-13 and YS-14 samples were taken with a GEMAX gravity corer (two Plexiglas tubes, $9 \mathrm{~cm}$ diameter); YS-9 and TB46 were collected with a Van Veen grab sampler. For the grab samples only surface sediments (uppermost $\mathrm{cm}$ ) were subsampled and used in this study. Sediment cores were cut into $1 \mathrm{~cm}$ slices within $24 \mathrm{~h}$ after sampling. To account for lower sediment accumulation rates on the rise, for SW-1, SW-2, SW-3 and SW-4 a higher resolution of $0.5 \mathrm{~cm}$ for the top $10 \mathrm{~cm}$ was chosen. The depositional age for all samples is thus between $\sim 8$ and $\sim 70$ years (depending on which sedimentation rates are employed). All samples were kept frozen throughout the expedition and freeze-dried upon arrival to Stockholm University laboratories. See Semiletov and Gustafsson (2009) for more information on the ISSS-08 expedition. For exact sampling locations see Table 1.

\subsection{Surface area $(\mathrm{SA})$}

All SA analyses have been performed on a Micromeritics Gemini VII Surface Area and Porosity analyzer. Freeze-dried subsamples of $\sim 0.7 \mathrm{~g}$ were heated at $400^{\circ} \mathrm{C}$ for $12 \mathrm{~h}$ and gently cooled down to room temperature to remove all organic material. Keil and Cowie (1999) have shown that this 
Table 1. List of surface sediment samples from the Laptev Sea transect.

\begin{tabular}{|c|c|c|c|c|c|c|c|c|c|c|c|}
\hline \multirow[t]{2}{*}{ ID } & \multirow[t]{2}{*}{$\begin{array}{r}\text { Sample } \\
\text { type }\end{array}$} & Lat & Long & $\begin{array}{l}\text { Water } \\
\text { depth }\end{array}$ & $\mathrm{OC}$ & SA & $\delta^{13} \mathrm{C}$ & $\Delta^{14} \mathrm{C}$ & $\mathrm{SiO}_{2}$ & $\mathrm{Al}_{2} \mathrm{O}_{3}$ & $\mathrm{CaO}$ \\
\hline & & ${ }^{\circ} \mathrm{N}$ & ${ }^{\circ} \mathrm{E}$ & $\mathrm{m}$ & $\mathrm{mg} \mathrm{g}^{-1}$ & $\mathrm{~m}^{2} \mathrm{~g}^{-1}$ & $\%$ & $\%$ & wt $\%$ & wt $\%$ & $\mathrm{wt} \%$ \\
\hline SW-1 & $0-0.5 \mathrm{~cm}$ & 78.942 & 125.243 & 3146 & 10.4 & 34.0 & -22.3 & -418 & 60.3 & 16.5 & 2.4 \\
\hline SW-2 & $0-0.5 \mathrm{~cm}$ & 78.581 & 125.607 & 2900 & 13.8 & 38.3 & -22.7 & -392 & 57.8 & 17.2 & 2.1 \\
\hline SW-3 & $0-0.5 \mathrm{~cm}$ & 78.238 & 126.150 & 2601 & 10.6 & 31.8 & -22.6 & -426 & 62.1 & 16.0 & 1.6 \\
\hline SW-4 & $0-0.5 \mathrm{~cm}$ & 77.855 & 126.664 & 2106 & 13.2 & 41.5 & -22.5 & -428 & 56.6 & 17.5 & 1.3 \\
\hline SW-6 & $0-1 \mathrm{~cm}$ & 77.142 & 127.378 & 92 & 7.6 & 14.9 & -23.2 & -364 & 72.0 & 12.6 & 1.7 \\
\hline SW-14 & $0-1 \mathrm{~cm}$ & 76.894 & 127.798 & 64 & 8.9 & 19.4 & -24.3 & -314 & 71.3 & 12.5 & 1.5 \\
\hline SW-23 & $0-1 \mathrm{~cm}$ & 76.171 & 129.333 & 56 & 15.8 & 21.7 & -25.0 & -333 & 68.9 & 13.6 & 1.4 \\
\hline YS-4 & $0-1 \mathrm{~cm}$ & 75.987 & 129.984 & 50 & $13.4^{\mathrm{a}}$ & 31.4 & $-24.8^{\mathrm{a}}$ & $-284^{\mathrm{a}}$ & 63.8 & 15.1 & 1.3 \\
\hline SW-24 & $0-1 \mathrm{~cm}$ & 75.599 & 129.558 & 46 & 10.7 & 37.0 & -24.3 & -437 & 62.5 & 15.4 & 1.2 \\
\hline YS-6 & $0-1 \mathrm{~cm}$ & 74.724 & 130.016 & 32 & $18.6^{\mathrm{a}}$ & 31.6 & $-25.6^{\mathrm{a}}$ & $-465^{\mathrm{a}}$ & 62.1 & 16.1 & 1.3 \\
\hline YS-9 & Grab & 73.366 & 129.997 & 23 & $13.1^{\mathrm{b}}$ & 16.9 & $-26.1^{b}$ & $-415^{b}$ & 70.8 & 14.0 & 1.3 \\
\hline YS-13 & $0-1 \mathrm{~cm}$ & 71.968 & 131.701 & 19 & $18.9^{\mathrm{a}}$ & 23.5 & $-25.9^{\mathrm{a}}$ & $-543^{\mathrm{a}}$ & 61.6 & 17.4 & 0.8 \\
\hline YS-14 & $0-1 \mathrm{~cm}$ & 71.630 & 130.050 & 7 & $19.1^{\mathrm{a}}$ & 11.4 & $-26.2^{\mathrm{a}}$ & $-504^{a}$ & 69.6 & 15.0 & 1.6 \\
\hline TB-46 & Grab & 72.700 & 130.180 & 6 & $25.8^{\mathrm{a}}$ & $12.0^{\mathrm{c}}$ & $-26.5^{\mathrm{a}}$ & $-436^{\mathrm{a}}$ & 67.9 & 15.2 & 1.8 \\
\hline
\end{tabular}

${ }^{a}$ Data from Vonk et al. (2012); ${ }^{\mathrm{b}}$ data from Tesi et al. (2016); ${ }^{\mathrm{c}}$ data from Karlsson et al. (2011).

Table 2. Biomarker results for surface sediment samples from the Laptev Sea transect.

\begin{tabular}{|c|c|c|c|c|c|c|c|c|c|c|c|c|}
\hline ID & $\begin{array}{l}\text { Lignin } \\
\mu \mathrm{g} \mathrm{m}^{-2}\end{array}$ & $\begin{array}{r}\text { Cutin } \\
\mu \mathrm{g} \mathrm{m}^{-2}\end{array}$ & $\begin{array}{l}\mathrm{HMW}^{\mathrm{a}} \\
\text { alkanes } \\
\mu \mathrm{g} \mathrm{m}^{-2}\end{array}$ & $\begin{array}{r}\mathrm{HMW}^{\mathrm{b}} \\
\text { acids } \\
\mu \mathrm{g} \mathrm{m}^{-2}\end{array}$ & $\mathrm{~S} / \mathrm{V}$ & $\mathrm{C} / \mathrm{V}$ & $\mathrm{Sd} / \mathrm{Sl}$ & Vd / Vl & $3,5-\mathrm{Bd} / \mathrm{V}$ & $\begin{array}{r}\text { CPI } \\
\text { alk }\end{array}$ & $\begin{array}{r}\text { CPI } \\
\text { acids }\end{array}$ & $\begin{array}{r}\text { acids/ } \\
\text { alk }\end{array}$ \\
\hline SW-1 & 0.56 & 0.063 & 0.14 & 0.27 & 1.1 & 0.09 & 1.3 & 0.98 & 0.43 & 2.5 & 4.1 & 1.9 \\
\hline SW-2 & 0.41 & 0.070 & 0.13 & 0.57 & 0.99 & 0.16 & 1.3 & 0.99 & 0.52 & 1.9 & 4.1 & 4.3 \\
\hline SW-3 & 0.34 & 0.061 & 0.13 & 0.75 & 0.92 & 0.14 & 1.3 & 0.95 & 0.61 & 1.7 & 4.1 & 6.0 \\
\hline SW-4 & 0.42 & 0.048 & 0.093 & 0.10 & 1.1 & 0.08 & 1.4 & 1.0 & 0.58 & 2.7 & 4.1 & 1.1 \\
\hline SW-6 & 0.68 & 0.12 & 0.18 & 0.67 & 0.90 & 0.19 & 1.2 & 1.0 & 0.46 & 2.9 & 4.4 & 3.7 \\
\hline SW-14 & 1.0 & 0.12 & 0.15 & 0.46 & 1.0 & 0.08 & 1.4 & 1.1 & 0.46 & 2.8 & 4.8 & 3.1 \\
\hline SW-23 & 0.97 & 0.17 & 0.16 & 1.2 & 0.96 & 0.11 & 1.3 & 1.1 & 0.48 & 3.2 & 4.4 & 7.4 \\
\hline YS-4 & 0.84 & 0.17 & 0.13 & 0.92 & 0.83 & 0.17 & 1.3 & 1.1 & 0.38 & 4.0 & 3.7 & 6.8 \\
\hline SW-24 & 0.76 & 0.23 & 0.18 & 1.6 & 0.84 & 0.19 & 1.2 & 1.1 & 0.43 & 4.0 & 3.9 & 8.9 \\
\hline YS-6 & 2.7 & 0.71 & 0.31 & 0.97 & 0.68 & 0.27 & 0.94 & 0.79 & 0.25 & 4.6 & 4.6 & 3.2 \\
\hline YS-9 & 10 & 2.7 & 0.45 & 1.1 & 0.60 & 0.31 & 0.65 & 0.60 & 0.16 & 4.7 & 4.1 & 2.3 \\
\hline YS-13 & 5.8 & 2.3 & 0.64 & 2.3 & 0.65 & 0.29 & 0.88 & 0.78 & 0.25 & 3.4 & 3.6 & 3.4 \\
\hline YS-14 & 34 & 9.0 & 1.1 & 12 & 0.66 & 0.42 & 0.57 & 0.50 & 0.11 & 6.0 & 5.9 & 11 \\
\hline TB-46 & 45 & 11 & $0.83^{\mathrm{c}}$ & $6.6^{\mathrm{c}}$ & 0.64 & 0.53 & 0.55 & 0.47 & 0.12 & $5.4^{\mathrm{c}}$ & $5.0^{c}$ & $7.9^{\mathrm{c}}$ \\
\hline
\end{tabular}

a Carbon chain lengths 23-34; ${ }^{b}$ carbon chain lengths 24-30. ${ }^{c}$ Recalculated data from Karlsson et al. (2011).

method yields statistically similar results to the method using removal with sodium pyrophosphate/hydrogen peroxide (Mayer, 1994). The samples were then desalted by repeated mixing with $50 \mathrm{~mL}$ of Milli-Q water and centrifugation (20 min at $8000 \mathrm{rpm}$ ), followed by further freezedrying. Directly prior to analysis they were degassed in a Micromeritics FlowPrep 060 Sample Degas System for $2 \mathrm{~h}$ at $200^{\circ} \mathrm{C}$ under a constant nitrogen flow. Each analysis was initiated by measuring the free space in the vial. The specific SAs were derived from six pressure-point measurements (relative pressure $p / p_{0}=0.05-0.3$, equilibration time $5 \mathrm{~s}$ ) with nitrogen as adsorbing gas (Brunauer et al., 1938). The instru- mental precision was $0.1-0.3 \mathrm{~m}^{2} \mathrm{~g}^{-1}$, which corresponds to a relative uncertainty of about $1 \%$. The performance of the instrument was monitored with the SA reference material carbon black $\left(21.0 \pm 0.75 \mathrm{~m}^{2} \mathrm{~g}^{-1}\right)$ provided by Micromeritics.

\subsection{X-Ray fluorescence (XRF)}

The mineral composition of $\sim 1 \mathrm{~g}$ freeze-dried, homogenized subsamples was also characterized with a wavelength dispersive sequential Philips PW2400 XRF spectrometer. Prior to the analysis, sediment samples were combusted for $12 \mathrm{~h}$ at $450^{\circ} \mathrm{C}$ to remove the organic fraction. The XRF was oper- 
ated under vacuum conditions on samples prepared as glass beads using lithium tetraborate and melted with a Claisse fluxer $\left(\sim 1150^{\circ} \mathrm{C}\right)$ (Mercone et al., 2001). The relative error was less than $0.6 \%$ for major elements and less than $3 \%$ for trace elements. In this study only $\mathrm{SiO}_{2}, \mathrm{Al}_{2} \mathrm{O}_{3}$ and $\mathrm{CaO}$ are reported.

\subsection{Bulk elemental and carbon isotope analysis}

Concentration and ${ }^{13} \mathrm{C}$ isotopic composition of TOC were determined at the Stable Isotope Laboratory, Department of Geological Sciences, Stockholm University. Homogenized subsamples of $\sim 10 \mathrm{mg}$ were repeatedly acidified $(\mathrm{HCl}$, $1.5 \mathrm{M}, \mathrm{Ag}$ capsules) to remove carbonates (Nieuwenhuize et al., 1994). TOC concentrations and ${ }^{13} \mathrm{C}$ isotopic composition were measured simultaneously with a Carlo Erba NC2500 elemental analyzer connected via a split interface to a Finnigan MAT Delta V mass spectrometer. TOC concentrations were blank corrected and the relative error was $<1 \%$. Stable isotope data are reported relative to VPDB using the $\delta^{13} \mathrm{C}$ notation.

Radiocarbon analyses of acidified samples were conducted at the US National Ocean Sciences Accelerator Mass Spectrometry (NOSAMS) facility of the Woods Hole Oceanographic Institution, USA, according to their standard routines (Pearson et al., 1998). The relative error of the measurements was $<0.5 \%$. Radiocarbon data are reported using the $\Delta^{14} \mathrm{C}$ notation following Stuvier and Polach (1977).

\subsection{Biomarkers}

\subsubsection{CuO-oxidation products}

Microwave-assisted alkaline $\mathrm{CuO}$ oxidation was performed according to the method established by Goñi and Montgomery (2000). Homogenized subsamples of $100-400 \mathrm{mg}$ of sediment (corresponding to $2-5 \mathrm{mg}$ OC) were combined with $300 \mathrm{mg}$ of copper(II) oxide and $50 \mathrm{mg}$ of ferrous ammonium sulfate and oxidized under oxygen-free conditions (degassed $\mathrm{NaOH}, 8 \mathrm{wt} \%$ ) at $150{ }^{\circ} \mathrm{C}$ for 90 min using an UltraWAVE Milestone 215 microwave oven. After oxidation, known amounts of trans-cinnamic acid and ethyl vanillin were added as recovery standards. Samples were acidified to $\mathrm{pH} 1$ with $\mathrm{HCl}(12 \mathrm{M})$ and repeatedly extracted with ethyl acetate. Anhydrous $\mathrm{Na}_{2} \mathrm{SO}_{4}$ was added to remove remaining water. The solvent was evaporated and extracts re-dissolved in pyridine. For quantification, subsamples were derivatized with bis-trimethylsilyl-trifluoroacetamide (BSTFA) $+1 \%$ trimethylchlorosilane (TMCS) and analyzed on a gas chromatograph/mass spectrometer (GC-MS, Agilent) in full scan mode using a DB5-MS capillary column $(60 \mathrm{~m} \times 250 \mu \mathrm{m}$, $0.25 \mu \mathrm{m}$ stationary phase thickness, Agilent $\mathrm{J} \& \mathrm{~W}$ ) with a temperature profile of initially $60^{\circ} \mathrm{C}$ followed by a ramp of $5^{\circ} \mathrm{C} \mathrm{min}{ }^{-1}$ until reaching and holding $300{ }^{\circ} \mathrm{C}$ for $5 \mathrm{~min}$. The quantification of lignin phenols, benzoic acids and $p$ - hydroxybenzenes was achieved by comparison to the response factors (key ions) of commercially available standards. For cutin-derived products, fatty acids and dicarboxylic acids the response factor of trans-cinnamic acid was used as in Goñi et al. (1998).

\subsubsection{Solvent-extractable lipids}

Wax lipids were extracted by means of accelerated solvent extraction (Dionex ASE 300) using dichloromethane: methanol $(9: 1)$ according to the method described by Wiesenberg et al. (2004). Pre-rinsed stainlesssteel vessels were loaded with $\sim 3 \mathrm{~g}$ of freeze-dried sediment, filled up with pre-combusted glass beads and pre-combusted glass fiber filters at both ends. Two extraction cycles were performed per sample applying a static pressure of $1500 \mathrm{psi}$ and a temperature of $80^{\circ} \mathrm{C}$ for $5 \mathrm{~min}$ after a heating phase of $5 \mathrm{~min}$. The flush volume was $50 \%$ of the $34 \mathrm{~mL}$ cell size with a purging time of $100 \mathrm{~s}$.

Extracts were further purified (addition of activated $\mathrm{Cu}$ for sulfur and anhydrous $\mathrm{Na}_{2} \mathrm{SO}_{4}$ for water removal) and then separated into a neutral and an acid fraction using BondElut cartridges (bonded phase $\mathrm{NH}_{2}$, Varian), eluting with dichloromethane : isopropanol $(2: 1)$ for the neutral and methyl tert-butyl ether with $4 \%$ acetic acid for the acid fraction according to the method described by van Dongen et al. (2008a). The neutral fraction was further separated into a polar and a non-polar fraction with an $\mathrm{Al}_{2} \mathrm{O}_{3}$ column. For each of the three compound classes $n$-alkanes (neutral non-polar fraction), $n$-alkanols (neutral polar fraction) and $n$-alkanoic acids (acid fraction) $\sim 10 \mathrm{mg}$ of one internal standard, $d_{50}$-tetracosane, 2-hexadecanol and $d_{39}$-eicosanoic acid respectively, were added to the sediment samples prior to extraction. All fractions were then analyzed on a GC-MS (Agilent) using the same column and temperature program as for the $\mathrm{CuO}$ products. The polar and acid fractions were derivatized with BSTFA $+1 \%$ TMCS prior to analysis. Quantification was performed using a five-point calibration curve with commercially available standards. Here, we only report data for HMW $n$-alkanes and $n$-alkanoic acids, where HMW refers to carbon chain lengths of $\geq 23$ for $n$-alkanes and $\geq 24$ for $n$-alkanoic acids.

\section{Results and discussion}

The fate of permafrost-released TerrOC across the Laptev Sea shelf is controlled by competing processes. Degradation and sorting, as well as replacement of TerrOC by autochthonous marine organic matter all co-occur to varying degrees during cross-shelf transport. To disentangle their effects on the fate of permafrost-released TerrOC we first report changes in bulk sediment and OC properties and then focus on differences on the molecular level. 


\subsection{Characterization of the transect on a bulk level}

Bulk TOC concentrations decreased across the shelf with highest values $(\sim 2 \%)$ at shallow water depths and lowest values on the shelf edge $(\sim 0.8 \%)$; at high water depths $(>2000 \mathrm{~m})$ concentrations were slightly higher $(\sim 1 \%)$ (Table 1). TOC values and the general pattern were in accordance with previous data from the Laptev Sea (Semiletov et al., 2005; Shakhova et al., 2015; Stein and Fahl, 2004; Vonk et al., 2012) and within the same range of those measured for the North American Arctic margin (Goñi et al., 2013).

Normalizing TOC concentrations to the mineral-specific SA helps to understand the influence of physical sorting and preferential deposition on the observed TOC trends since SA is correlated to the sediment grain size to a first-order approximation. To test if the mineral SA is altered by the input of autochthonous organisms with siliceous or carbonaceous skeleton (e.g., silicoflagellates/diatoms or foraminifera/shells respectively), the mineral composition of the sediments was examined by XRF analysis. There were no apparent trends with water depth for either $\mathrm{SiO}_{2} / \mathrm{Al}_{2} \mathrm{O}_{3}$ or $\mathrm{CaO} / \mathrm{Al}_{2} \mathrm{O}_{3}$ (Table 1); therefore, marine production is not expected to have a measurable effect and SA can thus be regarded as a conservative parameter. This was also confirmed by low biogenic silica concentrations for the Laptev Sea reported earlier (<1.4\%, Mammone, 1998).

The relationship between TOC and SA has been widely studied on continental margins (e.g., Blair and Aller, 2012; Keil et al., 1994; Mayer, 1994). The TOC/SA ratios of typical river suspended sediments range between 0.4 and $1 \mathrm{mg} \mathrm{m}^{-2}$ (Mayer, 1994). TOC / SA ratios $>1 \mathrm{mg} \mathrm{m}^{-2}$ have been found in areas with high TOC supply (e.g., river outlets) and where the deposited organic matter had spent little time under oxic conditions (short OET) (Mayer et al., 2002). Ratios $<0.4 \mathrm{mg} \mathrm{m}^{-2}$ generally correspond to sediments from deeper parts of the ocean and long OETs (e.g., Aller and Blair, 2006). Accordingly, the TOC / SA values along the Laptev Sea transect displayed a strong decrease from 2.2 and $1.7 \mathrm{mg} \mathrm{m}^{-2}$ close to the Lena River delta (water depths of 11 and $7 \mathrm{~m}$, respectively) to about $0.3 \mathrm{mg} \mathrm{m}^{-2}$ at water depths greater than $2000 \mathrm{~m}$ (Fig. 2a), proposing extensive TOC loss during cross-shelf transport.

Bulk TOC isotopes have been broadly used to distinguish between organic matter sources. Radiocarbon isotopes $\left({ }^{14} \mathrm{C}\right)$ convey information about the age of organic material, with younger $\mathrm{OC}$ having higher $\Delta^{14} \mathrm{C}$ values. Marine organic matter produced primarily from $\mathrm{CO}_{2}$ is expected to have modern ${ }^{14} \mathrm{C}$ signatures, whereas permafrost-derived TerrOC has aged both on land and during transport and has thus more depleted ${ }^{14} \mathrm{C}$ values. The $\Delta^{14} \mathrm{C}$ values for our Laptev Sea transect were generally low $(<-280 \%$ o, Fig. $2 b$, Table 1$)$, suggesting a significant input of pre-aged TerrOC (as in Vonk et al., 2012). Bulk TOC showed less depleted $\Delta^{14} \mathrm{C}$ signatures with increasing distance from land on the shelf (from about -500 to about $-340 \%$ on the outer shelf), reflecting
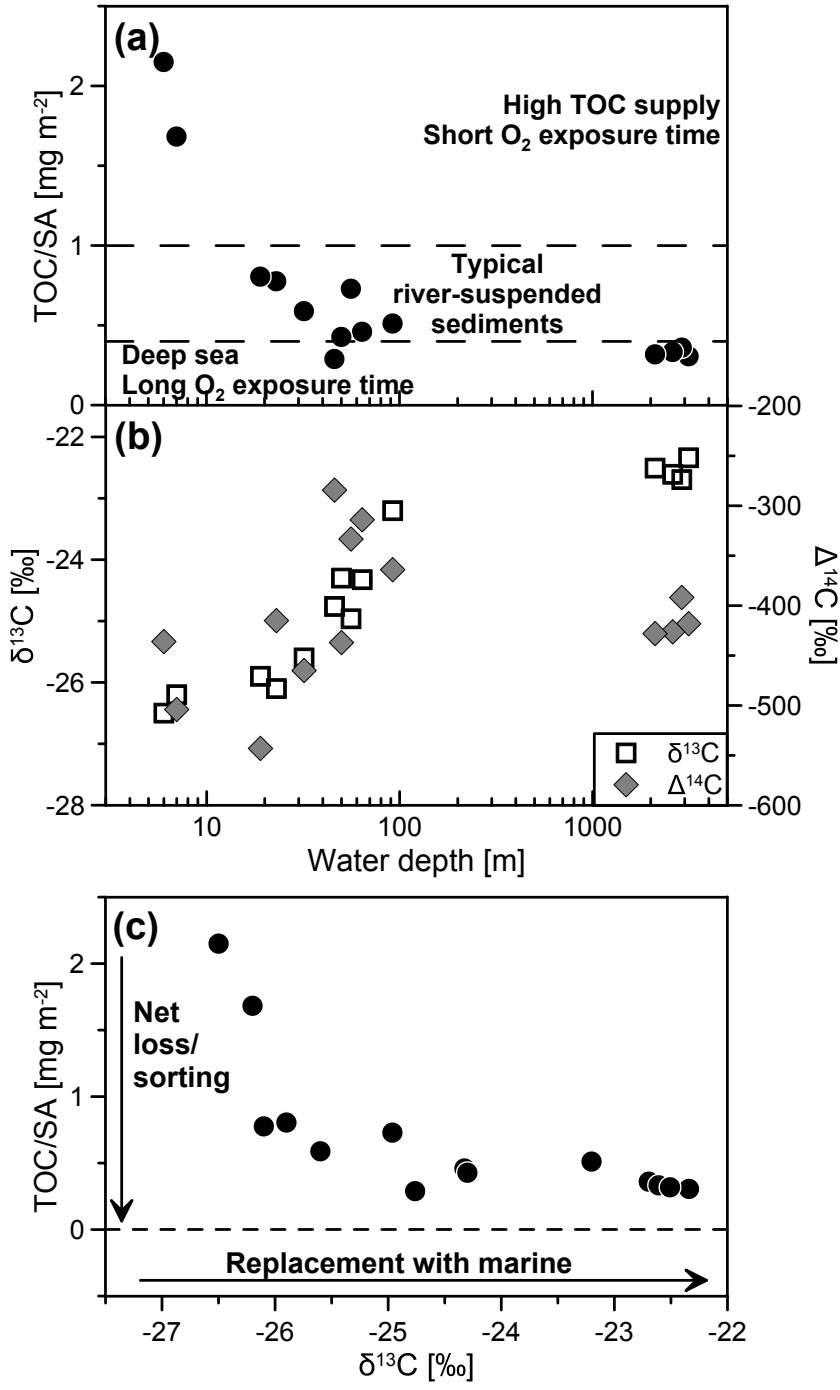

Figure 2. (a) The ratio of total organic carbon (TOC) to mineral surface area (SA). Typical values for deep sea, river-suspended sediments and high TOC supply are taken from Blair and Aller (2012). (b) The stable carbon isotopic signal $\left(\delta^{13} \mathrm{C}\right.$, open boxes) and the radiocarbon isotopic signal ( $\Delta^{14} \mathrm{C}$, filled diamonds). (c) The relationship between TOC / SA and $\delta^{13} \mathrm{C}$ can help to disentangle two processes occurring simultaneously during cross-shelf transport: the net loss (i.e., degradation) or sorting (i.e., hydraulically retaining) of TerrOC leads to a shift towards lower TOC / SA ratios, whereas the replacement/dilution with marine OC shifts the isotopic signature towards higher values.

a dilution of older TerrOC with younger marine material. On the slope and rise, however, $\Delta{ }^{14} \mathrm{C}$ values decreased again to about $-410 \%$. This difference may be a result of ageing during lateral transport and/or after deposition due to lower accumulation rates on slope and rise. The range between -340 and $-410 \%$ corresponds to a $\Delta^{14} \mathrm{C}$ age difference of about 900 years; however, the depositional age differences between shelf and slope samples were estimated to be less than 
80 years (see Sect. 2.2). Ageing after burial alone does therefore not explain the difference in $\Delta^{14} \mathrm{C}$. Keil et al. (2004) estimated a lateral transport time of 1800 years across the Washington margin $(158 \mathrm{~km})$ from $\Delta{ }^{14} \mathrm{C}$ data of bulk OC in surface sediments. For the $>200 \mathrm{~km}$ distance between midshelf and rise a bulk ageing of 900 years does therefore not seem unreasonable, particularly since the Washington margin, as opposed to the Laptev Sea shelf, is an active margin. The value from Keil et al. (2004) may therefore be regarded as a lower boundary. It has to be taken into account, however, that mainly the TerrOC fraction of the bulk OC is subject to such protracted lateral transport. Transport times would thus have to be significantly higher in order to explain this age difference for the entire bulk OC. One indication supporting this hypothesis of protracted lateral transport of TerrOC is the degradation status of TerrOC at the deep stations. All molecular degradation proxies point towards highly reworked material (see Sect. 3.3), suggesting that only the most refractory TerrOC fraction is found at great water depths off the continental margin. Alternatively, the lower $\Delta^{14} \mathrm{C}$ values at high water depths may be the consequence of more effective degradation of marine organic matter throughout the water column, resulting in a comparatively lower input of young autochthonous material. However, this latter scenario is not supported by the stable carbon isotopic signature, as values for $\delta^{13} \mathrm{C}$ increase from about $-24.3 \%$ on the mid-shelf to about $-22.5 \%$, suggesting a higher fraction of marine organic matter for the deep stations.

For stable carbon isotopes $\left({ }^{13} \mathrm{C}\right)$, terrigenous sources are generally more depleted than marine organic matter (Fry and Sherr, 1984). In this study, values for $\delta^{13} \mathrm{C}$ of TOC ranged between -26.5 and $-22.3 \%$. The trend towards more enriched TOC with increasing distance from the coast (Fig. 2b, Table 1) can be explained by a growing proportion of marine organic matter. However, the $\delta^{13} \mathrm{C}$ signature of the marine source appeared to be heavier than typical marine planktonic material in that region $(-26.7 \pm 1.2 \%$, Panova et al., $2015 ;-24 \pm 3 \%$, Vonk et al., 2012, and references therein). One possible explanation for this discrepancy is an underestimated influence of ice algae that were reported to have highly enriched $\delta^{13} \mathrm{C}$ values between -15 and $-18 \%$ (Schubert and Calvert, 2001). Significant seafloor deposition of ice algal biomass has been observed previously for the Arctic basins (Boetius et al., 2013). Another option would be a more refractory, isotopically enriched marine endmember $(-21.2 \%)$ as suggested by Magen et al. (2010). They argue that lighter isotopes are preferentially consumed by bacteria, which in turn enriches the remaining marine organic matter. Following their reasoning, the more enriched values observed for this transect may be interpreted as an increasing proportion of refractory marine organic matter.

Winterfeld et al. (2015b) analyzed surface water POC in the Lena River delta and found a mean $\delta^{13} \mathrm{C}$ of $-29.6 \pm 1.5 \%$. Karlsson et al. (2011) reported similarly depleted $\delta^{13} \mathrm{C}$ values for POC from the Buor-Khaya Bay
$(-29.0 \pm 2.0 \%$ ) , while their mean value for sedimentary OC for the same stations was significantly more enriched $(-25.9 \pm 0.4 \%$ ) and agreed well with our data for the shallow stations $(-26.2 \pm 0.3 \%$, stations YS-13, YS-14 and TB46). Lena River POC $\delta^{13} \mathrm{C}$ values from high-discharge periods agree well with the more enriched values we found for the shallow stations (Rachold and Hubberten, 1998). Stein and Fahl (2004), Semiletov et al. $(2011,2012)$ and Vonk et al. (2012) presented similar $\delta^{13} \mathrm{C}$ ranges and trends for sediments from parts of the Laptev Sea as is reported in the current study for the entire width of the Laptev Sea shelf. For the Arctic Amerasian Continental shelf, Naidu et al. (2000) reported contrasts in absolute $\delta^{13} \mathrm{C}$ values comparing surface sediment samples from different regions, but all commonly displayed an increasing trend for $\delta^{13} \mathrm{C}$ values across the shelf, suggesting a growing fraction of marine organic matter with increasing distance from the coast.

Combining TOC / SA ratios with stable isotope signatures $\left(\delta^{13} \mathrm{C}\right)$ may serve to disentangle two different processes, which occur synchronously during cross-shelf transport (as in Keil et al. 1997a): (1) the net loss of TerrOC and (2) the replacement of TerrOC with autochthonous marine OC. Net loss of TerrOC, caused by either degradation or hydrodynamic sorting during transport, has been quantified previously using TOC / SA ratios (e.g., Aller and Blair, 2006; Keil et al., 1997a). The carrying capacity of inorganic particles for OC is assumed to be a function of the SA (Mayer, 1994); a decrease in TOC / SA values can therefore be regarded as TOC net loss.

Replacement of TerrOC with autochthonous marine OC does not change this ratio. However, since marine OC is known to be isotopically enriched in $\delta^{13} \mathrm{C}$ over TerrOC, this process is recorded by an increasing isotopic signature. Along the Laptev Sea transect, both processes seemed to play an important role (Fig. 2c). High TOC / SA values close to the Lena River decreased sharply outbound in the nearshore regime, pointing to extensive net loss, while the increase in $\delta^{13} \mathrm{C}$ values was minor in this area. Once TOC / SA ratios were $<0.8 \mathrm{mg} \mathrm{m}^{-2}$ (water depths $>20 \mathrm{~m}$ ), the isotopic changes and thus the replacement of TerrOC with marine OC became increasingly important. Similar trends were observed for the Amazon River delta (Keil et al., 1997b).

However, the TOC / SA trend in the shallower sediments is likely driven by both degradation of OC bound to the mineral matrix during cross-shelf transport and sorting of vascular plant fragments that are retained in the inner shelf. A recent study (Tesi et al., 2016) showed that $\sim 50 \%$ of the total OC pool in the inner Laptev shelf surface sediments exists in the form of large vascular plant fragments. They are trapped close to the coast due to their size and resulting settling (Stoke's law), while the OC bound to the fine mineral matrix is more buoyant and transported offshore towards deeper waters. 


\subsection{Molecular indicators of organic matter sources}

\subsubsection{Biomarker distributions}

The abundances of different source-diagnostic molecular proxies have been extensively investigated to elucidate complex carbon-cycling mechanisms. In this study, a biomarker suite of $\mathrm{CuO}$ oxidation products and solvent-extractable lipids was analyzed in order to gain more insights on TerrOC sources and degradation status along the Laptev Sea transect. All biomarker concentrations were normalized to the sediment-specific SA instead of OC content to avoid the signals being overshadowed by other carbon pools. As shown by the lack of water-depth-related changes in the mineral composition (Sect. 3.1), mineral-matrix dilution by biogenic material is negligible.

Lignin-derived phenols have been widely used to trace TerrOC in the marine environment (e.g., Ertel and Hedges, 1984; Goñi and Hedges, 1995; Hedges and Mann, 1979). The lignin macro-molecule is only synthesized in vascular plants (and certain seaweed species that are not existing in the study area) to render stability to the cell walls. Lignin-derived phenols are typically grouped by phenol type (V: vanillyl phenols, i.e., vanillin, acetovanillone and vanillic acid; S: syringyl phenols, i.e., syringaldehyde, acetosyringone and syringic acid; $\mathrm{C}$ : cinnamyl phenols, i.e., $p$-coumaric and ferulic acids). Total lignin refers to the sum of the three groups. Across the shelf, lignin loadings decreased substantially with increasing distance from the coast/water depth $\left(45 \mu \mathrm{g} \mathrm{m}^{-2}\right.$ close to the coast and $0.43 \pm 0.09 \mu \mathrm{g} \mathrm{m}^{-2}$ for the deep stations; loss of $99.1 \pm 0.2 \%$, Fig. 3a, Table 2).

Cutin-derived hydroxy fatty acids are another compound class obtained from $\mathrm{CuO}$ oxidation, which have been used in parallel with lignin phenols (e.g., Goñi et al., 2000; Prahl et al., 1994). They are mainly associated with the soft tissues of vascular plants such as leaves and needles. Cutin acid loadings displayed a similar trend as lignin phenols $\left(11 \mu \mathrm{g} \mathrm{m} \mathrm{m}^{-2}\right.$ close to the coast, $0.061 \pm 0.010 \mu \mathrm{g} \mathrm{m}^{-2}$ for the deep stations; loss of $99.4 \pm 0.1 \%$, Fig. 3a, Table 2).

Similar values and sharp declines with increasing distance from the coast for lignin and cutin have been observed for the whole ESAS (Tesi et al., 2014) (Fig. 4 for comparison of lignin phenol concentrations with literature values for different Arctic margins). A recent study (Winterfeld et al., 2015a) for the Buor-Khaya Bay (5.8-17 m water depth) reported lignin phenol concentrations on the same order of magnitude, up to $40 \%$ higher for the shallowest samples, and decreasing with increasing depth. For the Beaufort Sea shelf, Goñi et al. (2000) found a less drastic decline in lignin phenols and cutin acids going from $5 \mathrm{~m}$ water depth to $210 \mathrm{~m}$, which likely reflected both lower concentrations in the shallow waters (factor of $\sim 2$ ) and a narrower and steeper shelf. Lignin phenols were also higher at greater water depths than on the ESAS. This may reflect the differences in bathymetry: since the Beaufort Sea shelf is not as wide as, but steeper

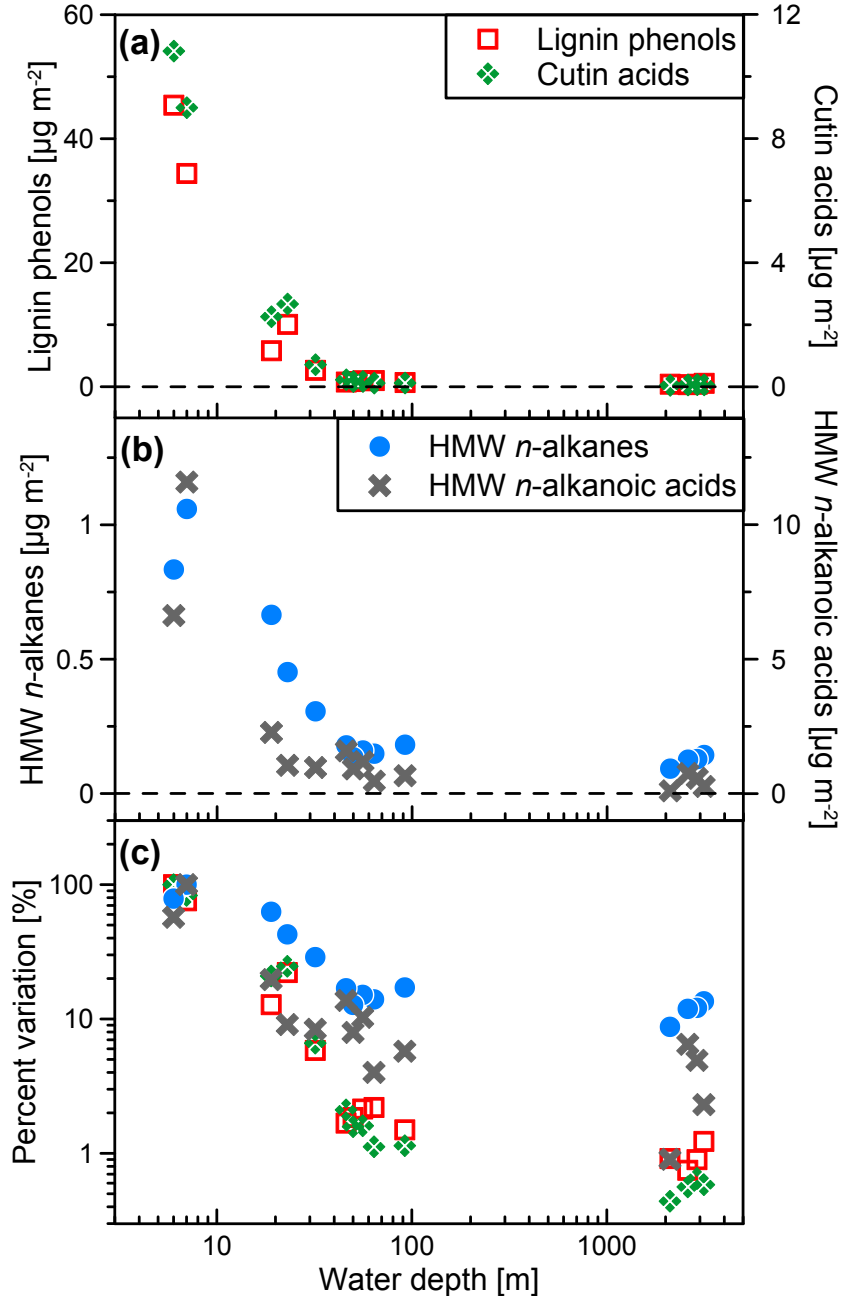

Figure 3. Terrigenous biomarker loadings across the shelf: (a) lignin phenols and cutin acids; (b) HMW $n$-alkanes and HMW $n$-alkanoic acids. (c) Comparison between the different biomarkers along the transect: lignin phenols, cutin acids, HMW $n$-alkanoic acids and $n$-alkanes where each is normalized to respective highest value (corresponding to $100 \%$ ).

than, the ESAS, lateral transport is possibly faster, leaving less time for organic matter to be degraded along the way. A comparison between different shelf-slope systems across the North American Arctic margin (Goñi et al., 2013) revealed very low lignin and cutin concentrations for the Canadian Archipelago, Lancaster Sound and Davis Strait, whereas both concentrations and trends with water depth for the Beaufort Sea, Chukchi Sea and Bering Sea were similar to the results from this study. An exception to these patterns was Barrow Canyon, where at water depths of $>2000 \mathrm{~m}$ lignin and cutin concentrations were as high as the ones observed close to the Lena River delta, pointing to efficient rapid TerrOC transfer with comparably short OETs through this active canyon (Goñi et al., 2013) (Figs. 4 and S1). 


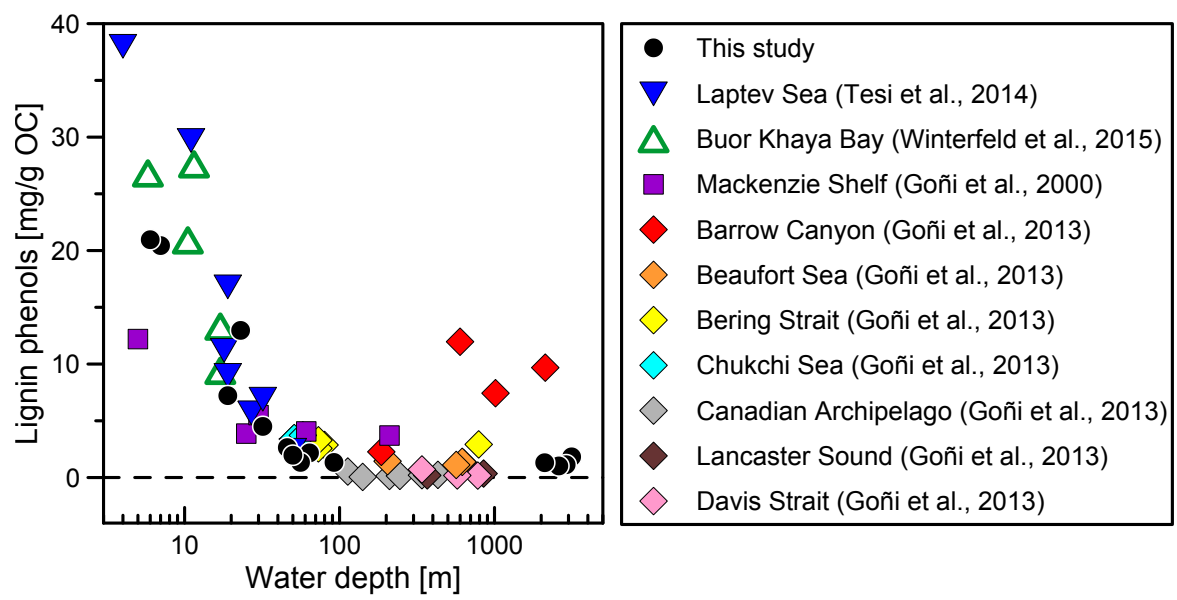

Figure 4. A comparison of lignin phenol data from this project to values from published studies around the Arctic Ocean. Similar decreasing trends with increasing water depth are observed for all systems but Barrow Canyon, where elevated lignin phenols concentrations are found even at depth of $>1000 \mathrm{~m}$.

Solvent extractable HMW $n$-alkanes and $n$-alkanoic acids make up the major part of epicuticular leaf waxes (Eglinton and Hamilton, 1967) and have been broadly employed as TerrOC biomarkers (for the Arctic Ocean, e.g., in van Dongen et al., 2008; Yunker et al., 1995, 2005). HMW wax lipids in this study also presented a decreasing trend with increasing water depth/distance from the coast, but to a lesser extent than lignin phenols or cutin acids (HMW $n$-alkanes: $1.1 \mu \mathrm{g} \mathrm{m}^{-2}$ close to the coast, $0.12 \pm 0.02 \mu \mathrm{g} \mathrm{m}^{-2}$ for the deep stations; HMW $n$-alkanoic acids: $12 \mu \mathrm{g} \mathrm{m}^{-2}$ close to the coast, $0.42 \pm 0.29 \mu \mathrm{g} \mathrm{m}^{-2}$ for the deep stations; loss of $89 \pm 2$ and $96 \pm 3 \%$, respectively, Fig. 3b, Table 2).

Previous studies in the same area reported similar lipid biomarkers concentrations, which confirm the magnitude of the decreasing trends with increasing water depth (Karlsson et al., 2011; Vonk et al., 2010) (Fig. S1 in the Supplement). HMW $n$-alkane concentrations in the Beaufort and the Chukchi Sea (Belicka et al., 2004; Yunker et al., 1993) are in accordance with the ones measured on the ESAS, but the shallowest sample on the Beaufort Shelf is $\sim 2$ times lower than the shallow ESAS samples (Fig. S1). This might imply that sediments transported by the Mackenzie River to the Beaufort Shelf have lower TerrOC concentrations than Lena River transported sediments. For the Mackenzie Shelf, Goñi et al. (2000) used lignin phenols and cutin acids to estimate a terrigenous $\delta^{13} \mathrm{C}$ endmember and therewith derived a terrigenous contribution of almost $80 \%$ for the shallowest sediments, while rough estimates from $\mathrm{C} / \mathrm{N}$ and $\delta^{13} \mathrm{C}$ data suggested that TerrOC made up only $30-50 \%$ of the organic carbon (Macdonald et al., 2004). For the Lena Delta, source apportionment calculations using $\delta^{13} \mathrm{C}$ and $\Delta^{14} \mathrm{C}$ data attributed up to $83 \%$ of the organic carbon to terrigenous sources (Vonk et al., 2012).

All TerrOC biomarker loadings displayed a strong decrease across the shelf, but their relative losses differ substan- tially between compound classes (Fig. 3c). These findings agree with previous results for the ESAS (Tesi et al., 2014), where similar differences between biomarkers were reported. A somewhat larger decrease was observed for lignin than for cutin, in contrast to this study. The different extents of biomarker losses for the different compound classes may either be attributed to preferential degradation of lignin phenols and cutin acids, implying that they are more labile than HMW $n$-alkanes and $n$-alkanoic acids, or sorting during transport, suggesting that they are associated with a sediment fraction that is hydraulically more retained and carried less efficiently to the outer shelf/slope. A recent study (Tesi et al., 2016) aimed to disentangle these two processes by analyzing different fractions of bulk surface sediments from three transects (yet with only three stations each) across the ESAS. The fractions were separated according to density $\left(1.8 \mathrm{~g} \mathrm{~cm}^{-3}\right.$ cutoff), size $(>63,38-63,<38 \mu \mathrm{m})$ and settling velocity $\left(1 \mathrm{~m} \mathrm{~d}^{-1}\right.$ cutoff). The highest lignin phenol abundance was found in low-density plant fragments $\left(26-55 \mathrm{mg} \mathrm{g}^{-1} \mathrm{OC}\right)$. These large particles have a higher settling velocity (Stokes' law) and are therefore hydraulically retained close to the coast. Cutin acids and plant wax lipids were mainly associated with the high-density fine $\left(<38 \mu \mathrm{m},>1 \mathrm{~m} \mathrm{~d}^{-1}\right)$ and ultrafine $\left(<38 \mu \mathrm{m},<1 \mathrm{~m} \mathrm{~d}^{-1}\right)$ mineral fractions. Within the fine and ultrafine fractions, which made up about $95 \%$ of the organic carbon on the outer shelf, they found drastic losses of all biomarkers with increasing distance from the coast, which they attributed to degradation during the protracted cross-shelf transport. Relative decreases appeared to depend on the number of functional groups of the compound class: $98 \pm 1 \%$ for lignin phenols, $97 \pm 1 \%$ for cutin acids, $96 \pm 1 \%$ for HMW $n$-alkanoic acids and $89 \pm 4 \%$ for HMW $n$-alkanes. According to that study, the steep cross-shelf gradients observed here for lignin phenols can be attributed to both hydrodynamic sorting close to the coast and degradation 
during transport. From the data in the current study alone, the two processes occurring in parallel - degradation and sorting during cross-shelf transport - cannot be disentangled. However, using the data from Tesi et al. (2016), we can make a rough correction for the sorting part to derive an estimate of the net extent of degradation. For the shallowest station in their study (same as here, TB-46), about $75 \%$ of the lignin phenols were associated with the low-density fraction that was retained close to the coast. If we thus assume only $25 \%$, i.e., 11 , of the $45 \mathrm{gg} \mathrm{m}^{-2}$ to be associated with the fine fraction that is actually transported across the shelf, we obtain a reduction by $96 \pm 1 \%$ that can be attributed to degradation (compared to $99.1 \%$ net loss). These results agree with the values presented in Tesi et al. (2016). For the other compounds analyzed 55-74\% are associated with the fine fraction even for the shallowest station and they therefore experience sorting to a lesser extent.

Degradation after burial is assumed to play only a minor role. Differences in sedimentation ages are expected to be small (Sect. 2.1) and a study on centennial-scale sediment cores from the East Siberian Sea (Bröder et al., 2016) detected no significant TerrOC degradation (as recorded by biomarker loss) with increasing sediment depth. Also in that study, lignin phenol and cutin acid loadings were on average 20 times higher on the inner than on the outer shelf, whereas for HMW $n$-alkanoic acids and $n$-alkanes the difference between inner and outer shelf was only a factor of $\sim 3-$ 5. Contrasts between the stations were found to be larger than down-core changes. This may be due to the fact that the cores in that study only encompassed about 1 century of sedimentation ages, while the protracted cross-shelf transport likely requires much longer timescales.

\subsubsection{Lignin phenol sources}

Relative distributions of different lignin phenol classes reveal more information on TerrOC sources since they are specific to different plant types. Syringyl phenols are not produced by gymnosperm (non-flowering) plants; elevated syringyl to vanillyl ratios (i.e., S / V > 1, Hedges and Parker, 1976) are therefore attributed to more lignin phenols from angiosperm (flowering) plants. These ratios have to be handled with care, though, because the preferential degradation of syringyl phenols by white- and brown-rot fungi on land can also alter S / V ratios (Hedges et al., 1988). S / V values for the Laptev Sea transect increased with increasing water depth from $\sim 0.65$ for the inner shelf to $\sim 1.0$ for the slope/rise sediments (Fig. 5a, Table 2). This trend can either be explained by preferential degradation of gymnosperm material or sorting during transport. Tesi et al. (2014) measured generally lower values for S / V (ESAS average: 0.47; for only Lena-watershed-dominated locations: 0.42) recording no trend with water depth (Fig. S1 for comparisons with other studies). Their deepest station was located at only $69 \mathrm{~m}$ water depth, though, whereas in this study sediments from
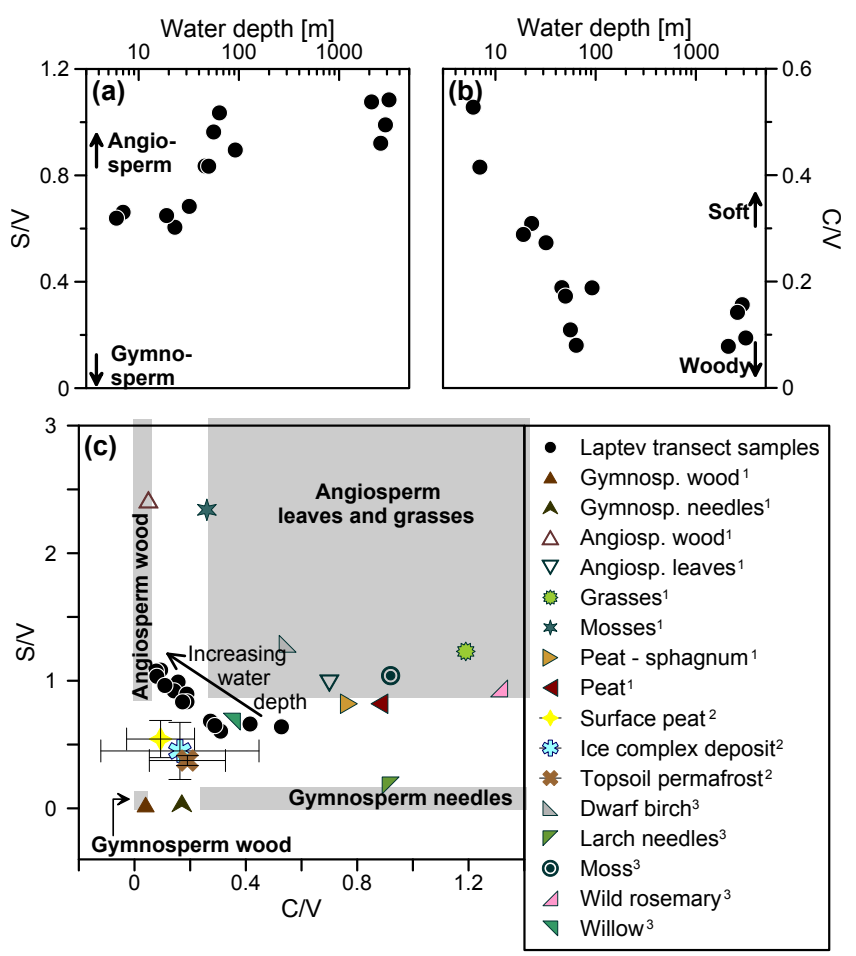

Figure 5. The lignin phenol composition carries source information. (a) an increasing ratio of syringyl to vanillyl phenols (S / V) suggests relatively more angiosperm material. (b) A decreasing ratio of cinnamyl to vanillyl phenols $(\mathrm{C} / \mathrm{V})$ implies an increasing relative contribution of woody material compared to soft tissues. (c) Comparison of $\mathrm{S} / \mathrm{V}$ and $\mathrm{C} / \mathrm{V}$ with the endmembers for different Arctic plants as compiled from different studies by Amon et al. (2012, and references therein, here marked with 1); ice-complex deposit and topsoil permafrost as determined by Tesi et al. (2014, here marked with 2) and more plant species measured by Winterfeld et al. (2015a, here marked with 3 ). The boxes indicate typical ranges of $\mathrm{S} / \mathrm{V}$ and $\mathrm{C} / \mathrm{V}$ for different vascular plant tissues in different locations (e.g., Goñi et al., 2000).

down to $3146 \mathrm{~m}$ water depth were analyzed. S / V ratios in Buor-Khaya Bay surface sediments (Winterfeld et al., 2015a) were also lower $(0.43 \pm 0.02$ on average $)$ and displayed no trend with water depth. Within the water depth interval they studied $(5.8-17 \mathrm{~m})$, however, the samples analyzed in this study had also quite homogeneous $S / V$ ratios $(0.64 \pm 0.02)$. Two sediment cores from the East Siberian Sea (Bröder et al., 2016) showed also lower S / V values (inner shelf surface sediment: 0.62 ; outer shelf surface sediment: 0.50$)$, displaying no clear trends over time/down-core. For the Beaufort Sea shelf Goñi et al. (2000) detected rather high values (0.54-1.71), which (besides the very high value at $61 \mathrm{~m}$ water depth) agree with the data from this study. Other transects across the North American Arctic margin (Goñi et al., 2013) had slightly lower S / V ratios with no observed trends with water depth. 
The ratio of cinnamyl to vanillyl phenols $(\mathrm{C} / \mathrm{V})$ is associated with the relative contributions of woody vs. soft material because only non-woody vascular plants synthesize cinnamyl phenols (Hedges and Mann, 1979a). This ratio admittedly decreases with ongoing degradation (Opsahl and Benner, 1995) and may therefore not be used as an unambiguous source indicator. We observed that $\mathrm{C} / \mathrm{V}$ values strongly decreased across the Laptev Sea Shelf from $\sim 0.5$ (close to the Lena River outlet) to $\sim 0.1$ (on the slope/rise, Fig. $5 b$, Table 2), which may reflect the preferential degradation of soft tissues. This trend is not likely caused by hydrodynamic sorting, since typically the larger, low-density, woody plant fragments are retained in shallower water, whereas finer material is transported further across the shelf (e.g., Keil et al., 1994; Tesi et al., 2016).

$\mathrm{C} / \mathrm{V}$ ratios in Buor-Khaya Bay sediments (Winterfeld et al., 2015a) in shallow waters were on average lower and more homogeneous $(0.17 \pm 0.03)$ than those measured in this study $(0.41 \pm 0.12$ for the corresponding depth interval) (Fig. S1 for comparisons with other studies). C / V values for the entire ESAS were on average $0.15(0.14 \pm 0.07$ for only Lena-dominated waters) with no water depth trend (Tesi et al., 2014). In shallow sediment cores from the East Siberian Sea, Bröder et al. (2016) measured C / V ratios of 0.20 (inner shelf) and 0.13 (outer shelf) for the surface sediments with no significant trend over sediment depth. For the Mackenzie Shelf C / V values ranged between 0.16 and 0.32 and slightly increased with increasing water depth (Goñi et al., 2000). In contrast, in the Bering Sea, Chukchi Sea, Barrow Canyon, Canadian Archipelago, Lancaster Sound and Davis Strait there were no C / V trends observed (Goñi et al., 2013), with lower values in the Canadian part $(0.10 \pm 0.12)$ and highest values on the Beaufort Sea slope, where values slightly decreased with increasing depth $(0.39 \pm 0.07)$.

A comparison to the $\mathrm{S} / \mathrm{V}-\mathrm{C} / \mathrm{V}$ signatures of potential Arctic plant endmembers (compiled by Amon et al., 2012, and citations therein, Tesi et al., 2014, and Winterfeld et al., 2015a) showed that lignin phenols likely derive from both angiosperm and gymnosperm soft tissues in the shallower samples, closely matching with willow (Salix) tissues measured by Winterfeld et al. (2015a). With increasing water depths, angiosperm wood became the most important source material, while gymnosperm wood, grasses and mosses did not appear to contribute significantly to the overall lignin phenol fingerprint (Fig. 5c). As discussed earlier, this trend may well be a result of preferential degradation and sorting during cross-shelf transport and not derive from actual changes in source material.

\subsection{Degradation status of organic matter}

During degradation, syringyl and vanillyl phenol aldehydes are oxidized to carboxylic acids of the same phenol group. Increasing Sd / Sl and Vd / V1 ratios can therefore qualitatively indicate ongoing degradation of lignin phenols (Er- tel and Hedges, 1984; Hedges et al., 1988). For fresh plant material typical acid-to-aldehyde ratios are around $0.1-0.2$ (Hedges et al., 1988). Winterfeld et al. (2015a), however, found values as high as $\mathrm{Sd} / \mathrm{Sl}=0.80$ and $\mathrm{Vd} / \mathrm{Vl}=0.67$ for a moss species (Aulacomnium turgidum), $\mathrm{Sd} / \mathrm{Sl}=0.87$ for larch (Larix) needles and $\mathrm{Sd} / \mathrm{Sl}=0.49 \mathrm{Vd} / \mathrm{Vl}=0.41$ for wild rosemary (Ledum palustre). Sedges (Carex spp.), dwarf birch (Betula nana) and willow (Salix) range between $\mathrm{Sd} / \mathrm{Sl}=0.13-0.24$ and $\mathrm{Vd} / \mathrm{Vl}=0.18-0.23$.

The ratio of $\mathrm{CuO}$ oxidation-derived 3,5-dihydroxybenzoic acid to vanillyl phenols $(3,5-\mathrm{Bd} / \mathrm{V})$ also serves as a proxy for degradation as $3,5-\mathrm{Bd}$ is formed during humification likely occurring in soils (Gordon and Goñi, 2004; Hedges et al., 1988; Prahl et al., 1994; Tesi et al., 2014). For this reason, this proxy can trace mineral-rich soil organic matter in contrast to vascular plant debris (e.g., Dickens et al., 2007; Prahl et al., 1994) as well as degradation during cross-shelf transport (Tesi et al., 2016).

$\mathrm{Sd} / \mathrm{Sl}, \mathrm{Vd} / \mathrm{Vl}$ and 3,5-Bd / V all increased along the transect, implying more degraded material with increasing residence time in the shelf system (Fig. 6a, Table 2). There appeared to be no differences between outer shelf/slope and rise, which may indicate that TerrOC on the slope is already highly reworked. In contrast, Tesi et al. (2014) found no correlation between $\mathrm{Sd} / \mathrm{Sl}$ or $\mathrm{Vd} / \mathrm{Vl}$ and distance from the coast, while 3,5-Bd / V significantly increased with increasing distance from the coast (Fig. S2 for comparisons with other studies). Sd / S1 values for the Buor-Khaya Bay from Winterfeld et al. (2015a) were slightly higher $(1.04 \pm 0.24)$ than samples from the corresponding water depths in this study $(0.66 \pm 0.15)$, whereas $\mathrm{Vd} / \mathrm{Vl}$ values were significantly higher $(1.28 \pm 0.30$ compared to $0.59 \pm 0.14)$. Measurements for the Mackenzie Shelf agreed with the ones in this study $(\mathrm{Sd} / \mathrm{Sl}=0.81 \pm 0.25$ compared to $1.01 \pm 0.33$ for the corresponding water depths; $\mathrm{Vd} / \mathrm{Vl}=0.69 \pm 0.14$ to $0.86 \pm 0.26 ; 3,5-\mathrm{Bd} / \mathrm{V}=0.19 \pm 0.04$ to $0.31 \pm 0.15)$ but did not show a trend with water depth (Goñi et al., 2000).

Tesi et al. (2016) observed lower acid/aldehyde ratios for the lignin-rich low-density fraction compared to the other fractions (high density with different grain sizes and settling velocities) in coastal surface sediments from the ESAS. With increasing distance from the coast, these values increased, whereas for the other fractions there were no apparent trends. These findings were interpreted as relatively fresh lignin in the low-density fraction (rich in large plant fragments) compared to the relatively degraded lignin that had likely experienced leaching and adsorbed to the fine mineral fractions (i.e., mineral-bound OC). Bulk 3,5-Bd / V values are potentially affected by both sorting and degradation, as they increased with decreasing particle size (fine and ultrafine fractions had the most degraded signal and are preferentially transported to the outer shelf) and across the shelf in each of the fractions.

The carbon preference indices for HMW $n$-alkanes and HMW $n$-alkanoic acids have also been widely applied as 


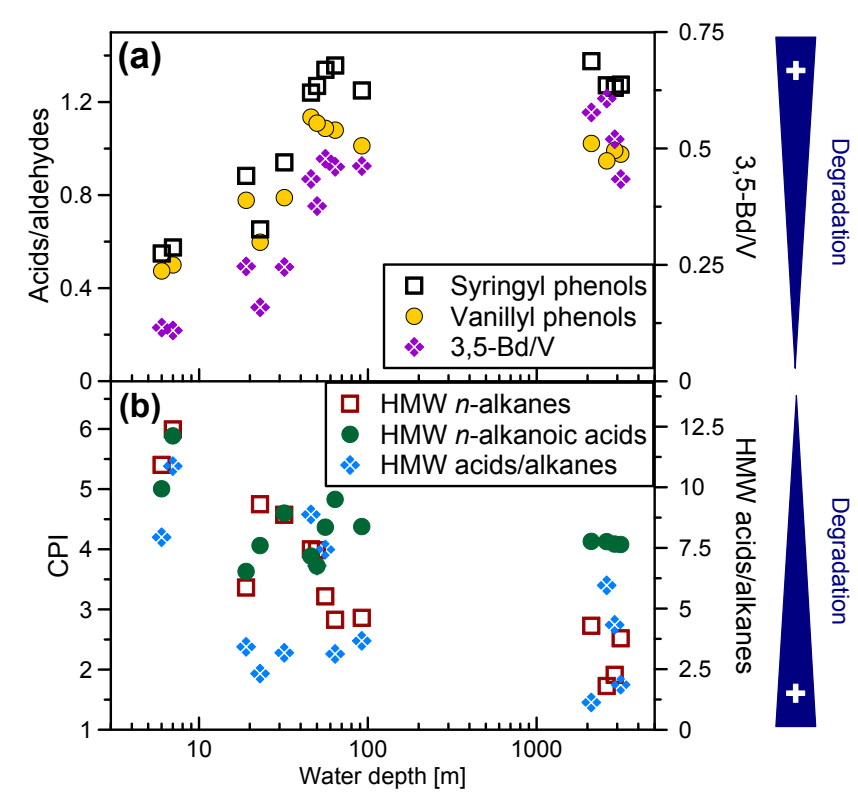

Figure 6. Degradation proxies for TerrOC, where blue triangles point toward lower extent of degradation: (a) $\mathrm{CuO}$-oxidationderived ratios $\mathrm{Sd} / \mathrm{Sl}, \mathrm{Vd} / \mathrm{Vl}$ and 3,5-Bd / V. (b) Carbon preference indices (CPI) of HMW $n$-alkanes and $n$-alkanoic acids and the ratio of HMW $n$-alkanoic acids to HMW $n$-alkanes.

degradation proxies for plant waxes in marine sediments (for the ESAS, e.g., van Dongen et al., 2008; Fahl and Stein, 1997; Fernandes and Sicre, 2000; Vonk et al., 2010). It measures the ratio of odd-to-even numbers of carbon chain lengths of HMW lipids and is based on the preference of odd carbon chain lengths for HMW $n$-alkanes in fresh plant material (even carbon chain lengths for HMW $n$-alkanoic acids; Eglinton and Hamilton, 1967). With ongoing degradation this preference is lost and the CPI approaches 1 (Bray and Evans, 1961).

We observed that the HMW $n$-alkane CPI presented a similar pattern to that of the lignin-phenol-based degradation indices. However, the HMW $n$-alkanoic acid CPI did not show as much of a degradation trend (HMW $n$-alkane CPI: $\sim 5.7$ close to the coast, $\sim 2.2$ for the deep stations; HMW $n$-alkanoic acids: $\sim 5.4$ close to the coast, $\sim 4.1$ for the deep stations; Fig. 6b, Table 2). Karlsson et al. (2011) measured lipid CPIs in the Buor-Khaya Bay with $10-80 \mathrm{~km}$ distance to the coast and obtained similar results to this $\sim 800 \mathrm{~km}$ cross-shelf study, with higher values closer to the river delta (Fig. S2 for comparisons with other studies). Their data appear to have a wider spread, though, which might be due to the narrower dynamic range. Fahl and Stein (1997) also reported a large range of $n$-alkane CPI values $(<0.2$ to $>5)$ for Laptev Sea sediments. Fernandes and Sicre (2000) analyzed sediments from the Kara Sea and from the major rivers discharging into this sea, the $\mathrm{Ob}$ and Yenisei rivers. In the marine environment and the Ob River, they observed HMW $n$-alkane CPI values between 4.8 and 5.3, similar to those found at shallow water depths in this study. For the Yenisei River and mixing zone, they found higher CPI values, pointing to fresher material being transported there. Vonk et al. (2010) recorded HMW $n$-alkane CPI values for sediments along the East Siberian Sea-Kolyma paleoriver transect (across the East Siberian Sea) shelf that decreased from $>7.5$ to $<4.0$ with increasing distance from the river mouth, overall higher than in this study but confirming the general trend to more degraded material on the outer shelf. Tesi et al. (2016) found HMW $n$-alkanoic acid CPI values to decrease with decreasing particle size with no significant trends across the shelf in all but the low-density fraction, which is largely retained close to the shore. The HMW $n$-alkane CPI values in that study, however, showed no systematical differences between different fractions, but an overall decreasing trend with increasing distance from the coast.

When undergoing degradation, HMW $n$-alkanoic acids may also lose their functional groups, turning them into HMW $n$-alkanes (Meyers and Ishiwatari, 1993). The slightly decreasing ratio of HMW $n$-alkanoic acids to $n$-alkanes also hints at more degraded material with increasing water depth, although, due to a rather large variability, this trend is not significant (Fig. 6b, Table 2). For the Buor-Khaya Bay surface sediments Karlsson et al. (2011) obtained similar results (0.48-10.7, here 1.1-10.9) with higher values closer to the river delta (Fig. S2 for comparisons with other studies). Along the Kolyma paleoriver transect, Vonk et al. (2010) measured HMW $n$-alkanoic acid to $n$-alkane ratios between 1 and 6 with no clear trend with increasing distance from the river mouth. Tesi et al. (2016) found decreasing values with increasing distance from the coast with no differences between the fractions. Two sediment cores from inner and outer East Siberian Sea recording about 1 century of sedimentation showed no clear trend in CPI or HMW $n$-alkanoic acid / $n$-alkane towards more degraded TerrOC with increasing sediment depth (Bröder et al., 2016), but displayed a similar difference between inner and outer shelf as seen in this study. This contrasting behavior for crossshelf and down-core trends may be caused by significantly different timescales for the two processes: about a century in situ/after burial compared to potentially several millennia long lateral transport. Furthermore, the degradation efficiency is likely higher under the oxic conditions prevailing during cross-shelf lateral transport (Keil et al., 2004) than in the anoxic conditions that predominate below a few millimeters of sediments on the ESAS (e.g., Boetius and Damm, 1998). Comparing in situ to transport-related OETs on the wide Arctic shelves could potentially resolve the observed discrepancies.

\section{Concluding remarks and future research directions}

Across the Laptev Sea from the Lena River mouth to the deep sea of the Arctic interior a considerable loss of TerrOC has 
been observed on both bulk and molecular level. All terrestrial biomarkers display a massive decline with increasing water depth along this high-resolution transect due to hydrodynamic sorting and degradation during transport. TerrOC seems to be also qualitatively more degraded on the outer shelf, slope and rise compared to inner shelf and coastal areas.

These results corroborate and expand previous findings for the East Siberian Arctic Shelf, showing that the shelf seas in this region function as an active reactor for TerrOC. Since the East Siberian Arctic Shelf belongs to the widest and shallowest continental margins on Earth, cross-shelf transport times and thus the time spent in oxic sediments are expected to be comparatively long. This stands in contrast to, e.g., the Mackenzie basin, which is thought to act as a geological sink for organic carbon due to its TerrOC burial (Hilton et al., 2015). For narrower Arctic shelves in general, where transport times can be expected to be much shorter, organic matter transfer towards the deeper basins appears to be much more efficient, with high TerrOC concentrations in surface sediments even at greater water depths (e.g., Barrow Canyon; Goñi et al., 2013). It can therefore be assumed that the crossshelf transport time exerts first-order control over the extent of TerrOC degradation. With ongoing global warming, rising permafrost-derived organic carbon input from river-sediment discharge and coastal erosion is expected to reach the marine environment. It is therefore crucial to better constrain cross-shelf transport times in order to determine a TerrOC degradation rate and thereby contribute to quantifying potential carbon-climate feedbacks.

\section{Data availability}

Data used to generate all figures are available in the paper as tables and on the Bolin Centre Database at http://bolin.su.se/ data/Broder-2016-2.

\section{The Supplement related to this article is available online at doi:10.5194/bg-13-5003-2016-supplement.}

Acknowledgements. We thank crew and personnel of the IB ODEN, the R/V Yakob Smirnitskyi and the TB0012. The SWERUS-C3 and the International Siberian Shelf Study 2008 (ISSS-08) expeditions were supported by the Knut and Alice Wallenberg Foundation, Headquarters of the Far Eastern Branch of the Russian Academy of Sciences, the Swedish Research Council (VR contract no. 6212004-4039, 621-2007-4631 and 621-2013-5297), the US National Oceanic and Atmospheric Administration (OAR Climate Program Office, NA08OAR4600758/Siberian Shelf Study), the Russian Foundation of Basic Research RFFI (08-05-13572, 08-05-00191-a and 07-05-00050a), the Swedish Polar Research Secretariat, the Nordic Council of Ministers and the US National Science
Foundation (OPP ARC 0909546). Lisa Bröder also acknowledges financial support from the Climate Research School of the Bolin Climate Research Centre. Tommaso Tesi also acknowledges EU financial support as a Marie Curie fellow (contract no. PIEF-GA2011-300259), contribution no. 1900 of ISMAR-CNR Sede di Bologna. Joan A. Salvadó also acknowledges EU financial support as a Marie Curie grant (FP7-PEOPLE-2012-IEF; project 328049). Igor Semiletov thanks the Russian Government for financial support (mega-grant no. 14.Z50.31.0012). Oleg V. Dudarev thanks the Russian Science Foundation (grant no. 15-17-20032). Furthermore we would like thank Francien Peterse, Xiaojuan Feng and one anonymous reviewer for their constructive comments, which helped to improve the manuscript.

Edited by: F. Peterse

Reviewed by: X. Feng and one anonymous referee

\section{References}

Aller, R. C. and Blair, N. E.: Carbon remineralization in the Amazon-Guianas tropical mobile mudbelt: A sedimentary incinerator, Cont. Shelf Res., 26, 2241-2259, 2006.

Amon, R. M. W., Rinehart, A. J., Duan, S., Louchouarn, P., Prokushkin, A., Guggenberger, G., Bauch, D., Stedmon, C., Raymond, P. A., Holmes, R. M., McClelland, J. W., Peterson, B. J., Walker, S. A., and Zhulidov, A. V.: Dissolved organic matter sources in large Arctic rivers, Geochim. Cosmochim. Acta, 94, 217-237, 2012.

Belicka, L. L., Macdonald, R. W., Yunker, M. B., and Harvey, H. R.: The role of depositional regime on carbon transport and preservation in Arctic Ocean sediments, Mar. Chem., 86, 65-88, 2004.

Blair, N. E. and Aller, R. C.: The Fate of Terrestrial Organic Carbon in the Marine Environment, Ann. Rev. Mar. Sci., 4, 401-423, 2012.

Boetius, A. and Damm, E.: Benthic oxygen uptake, hydrolytic potentials and microbial biomass at the Arctic continental slope, Deep-Sea Res. Pt. I, 45, 239-275, 1998.

Boetius, A., Albrecht, S., Bakker, K., Bienhold, C., Felden, J., Fernández-Méndez, M., Hendricks, S., Katlein, C., Lalande, C., Krumpen, T., Nicolaus, M., Peeken, I., Rabe, B., Rogacheva, A., Rybakova, E., Somavilla, R., and Wenzhöfer, F.: Export of algal biomass from the melting Arctic sea ice, Science, 339, 14301432, 2013.

Bray, E. and Evans, E.: Distribution of n-paraffins as a clue to recognition of source beds, Geochim. Cosmochim. Acta, 22, 2-15, 1961.

Brunauer, S., Emmett, P. H., and Teller, E.: Adsorption of Gases in Multimolecular Layers, J. Am. Chem. Soc., 60, 309-319, 1938.

Bröder, L., Tesi, T., Andersson, A., Eglinton, T. I., Semiletov, I. P., Dudarev, O. V., Roos, P., and Gustafsson, Ö.: Historical records of organic matter supply and degradation status in the East Siberian Sea, Org. Geochem., 91, 16-30, 2016.

Charkin, A. N., Dudarev, O. V., Semiletov, I. P., Kruhmalev, A. V., Vonk, J. E., Sánchez-García, L., Karlsson, E., Gustafsson, O., Gustafsson, Ö., and Gustafsson, O.: Seasonal and interannual variability of sedimentation and organic matter distribution in the Buor-Khaya Gulf: The primary recipient of input from Lena 
River and coastal erosion in the southeast Laptev Sea, Biogeosciences, 8, 2581-2594, doi:10.5194/bg-8-2581-2011, 2011.

Dethleff, D.: Entrainment and export of Laptev Sea ice sediments, Siberian Arctic, J. Geophys. Res.-Oceans, 110, C07025, doi:10.1029/2005JC002897, 2005.

Dethleff, D.: Dense water formation in the Laptev Sea flaw lead, J. Geophys. Res.-Oceans, 115, C12022, doi:10.1029/2009JC006080, 2010.

Dickens, A. F., Gudeman, J. A., Gélinas, Y., Baldock, J. A., Tinner, W., Hu, F. S., and Hedges, J. I.: Sources and distribution of CuOderived benzene carboxylic acids in soils and sediments, Org. Geochem., 38, 1256-1276, 2007.

Dmitrenko, I. A., Kirillov, S. A., and Bruno Tremblay, L.: The long-term and interannual variability of summer fresh water storage over the eastern Siberian shelf: Implication for climatic change, J. Geophys. Res.-Oceans, 113, C03S06, doi:10.1029/2007JC004304, 2008.

Eglinton, G. and Hamilton, R. J.: Leaf epicuticular waxes, Science, 156, 1322-1335, 1967.

Eicken, H., Reimnitz, E., Alexandrov, V., Martin, T., Kassens, H., and Viehoff, T.: Sea-ice processes in the Laptev Sea and their importance for sediment export, Cont. Shelf Res., 17, 205-233, 1997.

Ertel, J. R. and Hedges, J. I.: The lignin component of humic substances: Distribution among soil and sedimentary humic, fulvic, and base-insoluble fractions, Geochim. Cosmochim. Acta, 48, 2065-2074, 1984.

Fahl, K. and Stein, R.: Modern organic carbon deposition in the Laptev Sea and the adjacent continental slope: Surface water productivity vs. terrigenous input, Org. Geochem., 26, 379-390, 1997.

Feng, X., Vonk, J. E., van Dongen, B. E., Gustafsson, Ö., Semiletov, I. P., Dudarev, O. V, Wang, Z., Montluçon, D. B., Wacker, L., and Eglinton, T. I.: Differential mobilization of terrestrial carbon pools in Eurasian Arctic river basins, P. Natl. Acad. Sci. USA, 110, 14168-14173, 2013.

Feng, X., Gustafsson, Ö., Holmes, R. M., Vonk, J. E., van Dongen, B. E., Semiletov, I. P., Dudarev, O. V., Yunker, M. B., Macdonald, R. W., Montluçon, D. B., and Eglinton, T. I.: Multi-molecular tracers of terrestrial carbon transfer across the pan-Arctic: comparison of hydrolyzable components with plant wax lipids and lignin phenols, Biogeosciences, 12, 4841-4860, doi:10.5194/bg12-4841-2015, 2015

Fernandes, M. B. and Sicre, M. A.: The importance of terrestrial organic carbon inputs on Kara Sea shelves as revealed by $n$ alkanes, OC and $\delta^{13} \mathrm{C}$ values, Org. Geochem., 31, 363-374, 2000.

Fry, B. and Sherr, E. B.: $\delta^{13} \mathrm{C}$ Measurements as indicators of carbon flow in marine and freshwater ecosystems, Contrib. Mar. Sci., 27, 13-49, 1984.

Goñi, M. A. and Hedges, J. I.: Sources and reactivities of marinederived organic matter in coastal sediments as determined by alkaline $\mathrm{CuO}$ oxidation, Geochim. Cosmochim. Acta, 59, 29652981, 1995.

Goñi, M. A. and Montgomery, S.: Alkaline $\mathrm{CuO}$ oxidation with a microwave digestion system: Lignin analyses of geochemical samples, Anal. Chem., 72, 3116-3121, 2000.

Goñi, M. A., Ruttenberg, K. C., and Eglinton, T. I.: A reassessment of the sources and importance of land-derived organic mat- ter in surface sediments from the Gulf of Mexico, Geochim. Cosmochim. Acta, 62, 3055-3075, 1998.

Goñi, M. A., Yunker, M. B., MacDonald, R. W., and Eglinton, T. I.: Distribution and sources of organic biomarkers in arctic sediments from the Mackenzie River and Beaufort Shelf, Mar. Chem., 71, 23-51, 2000.

Goñi, M. A., O’Connor, A. E., Kuzyk, Z. Z., Yunker, M. B., Gobeil, C., and Macdonald, R. W.: Distribution and sources of organic matter in surface marine sediments across the North American Arctic margin, J. Geophys. Res.-Oceans, 118, 4017-4035, 2013.

Gordeev, V. V.: Fluvial sediment flux to the Arctic Ocean, Geomorphology, 80, 94-104, 2006.

Gordon, E. S. and Goñi, M. A.: Controls on the distribution and accumulation of terrigenous organic matter in sediments from the Mississippi and Atchafalaya river margin, Mar. Chem., 92, 331-352, 2004.

Guay, C. K. H., Falkner, K. K., Muench, R. D., Mensch, M., Frank, M., and Bayer, R.: Wind-driven transport for Eurasian Arctic rover discharge, J. Geophys. Res., 106, 11469-11480, 2001.

Gustafsson, Ö., Van Dongen, B. E., Vonk, J. E., Dudarev, O. V., and Semiletov, I. P.: Widespread release of old carbon across the Siberian Arctic echoed by its large rivers, Biogeosciences, 8, 1737-1743, doi:10.5194/bg-8-1737-2011, 2011.

Günther, F., Overduin, P. P., Sandakov, A. V., Grosse, G., and Grigoriev, M. N.: Short- and long-term thermo-erosion of ice-rich permafrost coasts in the Laptev Sea region, Biogeosciences, 10, 4297-4318, doi:10.5194/bg-10-4297-2013, 2013.

Hedges, J. I. and Mann, D. C.: The characterization of plant tissues by their lignin oxidation products, Geochim. Cosmochim. Acta, 43, 1803-1807, 1979a.

Hedges, J. I. and Mann, D. C.: The lignin geochemistry of marine sediments from the southern Washington coast, Geochim. Cosmochim. Acta, 43, 1809-1818, 1979b.

Hedges, J. I. and Parker, P. L.: Land-derived organic matter in surface sediments from the Gulf of Mexico, Geochim. Cosmochim. Acta, 40, 1019-1029, 1976.

Hedges, J. I., Blanchette, R. A., Weliky, K., and Devol, A. H.: Effects of fungal degradation on the $\mathrm{CuO}$ oxidation products of lignin: A controlled laboratory study, Geochim. Cosmochim. Acta, 52, 2717-2726, 1988.

Hilton, R. G., Galy, V., Gaillardet, J., Dellinger, M., Bryant, C., O’Regan, M., Gröcke, D. R., Coxall, H., Bouchez, J., and Calmels, D.: Erosion of organic carbon in the Arctic as a geological carbon dioxide sink, Nature, 524, 84-87, 2015.

Holmes, R. M., McClelland, J. W., Peterson, B. J., Shiklomanov, I. A., Shiklomanov, A. I., Zhulidov, A. V, Gordeev, V. V., and Bobrovitskaya, N. N.: A circumpolar perspective on fluvial sediment flux to the Arctic ocean, Global Biogeochem. Cy., 16, 14 45, 2002.

Holmes, R. M., McClelland, J. W., Peterson, B. J., Tank, S. E., Bulygina, E., Eglinton, T. I., Gordeev, V. V., Gurtovaya, T. Y., Raymond, P. a., Repeta, D. J., Staples, R., Striegl, R. G., Zhulidov, A. V., and Zimov, S. A.: Seasonal and Annual Fluxes of Nutrients and Organic Matter from Large Rivers to the Arctic Ocean and Surrounding Seas, Estuar. Coast., 35, 369-382, 2012.

Hugelius, G., Strauss, J., Zubrzycki, S., Harden, J. W., Schuur, E. A. G., Ping, C.-L., Schirrmeister, L., Grosse, G., Michaelson, G. J., Koven, C. D., O’Donnell, J. A., Elberling, B., Mishra, U., Camill, P., Yu, Z., Palmtag, J., and Kuhry, P.: Estimated stocks 
of circumpolar permafrost carbon with quantified uncertainty ranges and identified data gaps, Biogeosciences, 11, 6573-6593, doi:10.5194/bg-11-6573-2014, 2014.

Ivanov, V. V. and Golovin, P. N.: Observations and modeling of dense water cascading from the northwestern Laptev Sea shelf, J. Geophys. Res.-Oceans, 112, C09023, doi:10.1029/2006JC003882, 2007.

Jakobsson, M., Grantz, A., Kristoffersen, Y., and Macnab, R.: Physiography and Bathymetry of the Arctic Ocean, in: The Organic Carbon Cycle in the Arctic Ocean, edited by: Stein, R. and Macdonald, R. W., Springer-Verlag, Berlin Heidelberg, 1-5, 2004.

Karlsson, E. S., Charkin, A., Dudarev, O., Semiletov, I., Vonk, J. E., Sánchez-García, L., and Andersson, A.: Carbon isotopes and lipid biomarker investigation of sources, transport and degradation of terrestrial organic matter in the Buor-Khaya Bay, SE Laptev Sea, Biogeosciences, 8, 1865-1879, doi:10.5194/bg-81865-2011, 2011.

Karlsson, E. S., Brüchert, V., Tesi, T., Charkin, a, Dudarev, O., Semiletov, I., and Gustafsson, Ö.: Contrasting regimes for organic matter degradation in the East Siberian Sea and the Laptev Sea assessed through microbial incubations and molecular markers, Mar. Chem., 170, 11-22, 2014.

Keil, R. G., Tsamakis, E., Fuh, C. B., Giddings, J. C., and Hedges, J. I.: Mineralogical and textural controls on the organic composition of coastal marine sediments: Hydrodynamic separation using SPLITT-fractionation, Geochim. Cosmochim. Acta, 58, 879893, 1994.

Keil, R. G., Mayer, L. M., Quay, P. D., Richey, J. E., and Hedges, J. I.: Loss of organic matter from riverine particles in deltas, Geochim. Cosmochim. Acta, 61, 1507-1511, 1997a.

Keil, R. G., Tsamakis, E., and Wolf, N.: Relationships between organic carbon preservation and mineral surface area in Amazon fan sediments (Holes ${ }^{932} \mathrm{~A}$ and ${ }^{942} \mathrm{~A}$ ), Proceedings of the Ocean Drilling Program, 155, 531-538, 1997 b.

Keil, R. G. and Cowie, G. L.: Organic matter preservation through the oxigen-deficient zone of the NE Arabian Sea as discernerd by organic carbon: mineral surface area ratios, Mar. Geol., 161, 13-22, 1999.

Keil, R. G., Dickens, A. F., Arnarson, T., Nunn, B. L., and Devol, A. H.: What is the oxygen exposure time of laterally transported organic matter along the Washington margin?, Mar. Chem., 92, 157-165, 2004.

Macdonald, R. W., Naidu, A. S., Yunker, M. B., and Gobeil, C.: The Beaufort Sea: distribution, sources, fluxes and burial of organic carbon, in: The Organic Carbon Cycle in the Arctic Ocean, edited by: Stein, R. and Macdonald, R. W., Springer-Verlag, Berlin Heidelberg, 177-192, 2004.

Magen, C., Chaillou, G., Crowe, S. a., Mucci, A., Sundby, B., Gao, A., Makabe, R., and Sasaki, H.: Origin and fate of particulate organic matter in the southern Beaufort Sea - Amundsen Gulf region, Canadian Arctic, Estuar. Coast. Shelf S., 86, 31-41, 2010.

Mammone, K. A.: Sediment provenance and transport on the Siberian Arctic shelf, Oregon State University, 1998.

Mayer, L. M.: Surface area control of organic carbon accumulation in continental shelf sediments, Geochim. Cosmochim. Acta, 58, 1271-1284, 1994.

Mayer, L., Benninger, L., Bock, M., DeMaster, D., Roberts, Q., and Martens, C.: Mineral associations and nutritional quality of organic matter in shelf and upper slope sediments off Cape Hat- teras, USA: A case of unusually high loadings, Deep-Sea Res. Pt. II, 49, 4587-4597, 2002.

McClelland, J. W., Holmes, R. M., Peterson, B. J., Amon, R., Brabets, T., Cooper, L., Gibson, J., Gordeev, V. V., Guay, C., Milburn, D., Staples, R., Raymond, P. A., Shiklomanov, I., Stiegl, R., Zhulidov, A., Gurtovaya, T., and Zimov, S.: Development of a Pan-Arctic Database for River Chemistry From Corals to Canyons?: The Great Barrier Reef Margin Program, 89, 217218, 2008.

Mercone, D., Thomson, J., Abu-Zied, R. H., Croudace, I. W., and Rohling, E. J.: High-resolution geochemical and micropalaeontological profiling of the most recent eastern Mediterranean sapropel, Mar. Geol., 177, 25-44, 2001.

Meyers, P. A. and Ishiwatari, R.: Lacustrine organic geochemistryan overview of indicators of organic matter sources and diagenesis in lake sediments, Org. Geochem., 20, 867-900, 1993.

Naidu, A. S., Cooper, L. W., Finney, B. P., Macdonald, R. W., Alexander, C., and Semiletov, I. P.: Organic carbon isotope ratio $\left(\delta^{13} \mathrm{C}\right)$ of Arctic Amerasian Continental shelf sediments, Int. J. Earth Sci., 89, 522-532, 2000.

Nieuwenhuize, J., Maas, Y. E., and Middelburg, J. J.: Rapid analysis of organic carbon and nitrogen in particulate materials, Mar. Chem., 45, 217-224, 1994.

Opsahl, S. and Benner, R.: Early diagenesis of vascular plant tissues?: Lignin and cutin decomposition and biogeochemical implications, Geochim. Cosmochim. Acta, 59, 4889-4904, 1995.

Panova, E., Tesi, T., Pearce, C., Salvadó, J. A., Karlsson, E. S., Kruså, M., Semiletov, I. P., and Gustafsson, Ö.: Geochemical compositional differences of the supramicron planktondominated fraction in two regimes of the Marginal Ice Zone (MIZ) of the outer East Siberian Arctic Shelf, in AGU Fall Meeting, Conference Abstract C43A-0797, 2015.

Pearson, A., Mcnichol, A. P., Schneider, R. J., von Reden, K. F., and Zheng, Y.: Microscale AMS 14C measurement at NOSAMS, Radiocarbon, 40, 61-75, 1998.

Prahl, F. G., Ertel, J. R., Goñi, M. A., Sparrow, M. A., and Eversmeyer, B.: Terrestrial organic carbon contributions to sediments on the Washington margin, Geochim. Cosmochim. Acta, 58, 3035-3048, 1994.

Rachold, V. and Hubberten, H. W.: Carbon isotope composition of particulate organic material in east Siberian rivers, Land-Ocean Systems in the Siberian Arctic: Dynamics and History, 223-238, 1998.

Rachold, V., Grigoriev, M. N., Are, F. E., Solomon, S., Reimnitz, E., Kassens, H., and Antonow, M.: Coastal erosion vs riverine sediment discharge in the Arctic Shelf seas, Int. J. Earth Sci., 89, 450-459, 2000.

Rachold, V., Eicken, H., Gordeev, V. V, Grigoriev, M. N., Hubberten, H.-W., Lisitzin, A. P., Shevchenko, V. P., and Schirrmeister, L.: Modern Terrigenous Organic Carbon Input to the Arctic Ocean, The Organic Carbon Cycle in the Arctic Ocean, 33-55, 2004.

Sakshaug, E.: Primary and secondary production in the Arctic Seas, in: The Organic Carbon Cycle in the Arctic Ocean, edited by: Stein, R. and Macdonald, R. W., 57-81, 2004.

Salvadó, J. A., Tesi, T., Andersson, A., Ingri, J., Dudarev, O. V., Semiletov, I. P., and Gustafsson, Ö.: Organic carbon remobilized from thawing permafrost is resequestered by reactive iron on 
the Eurasian Arctic Shelf, Geophys. Res. Lett., 42, 8122-8130, 2015.

Sánchez-García, L., Alling, V., Pugach, S., Vonk, J., Van Dongen, B., Humborg, C., Dudarev, O., Semiletov, I., and Gustafsson, Ö.: Inventories and behavior of particulate organic carbon in the Laptev and East Siberian seas, Global Biogeochem. Cy., 25, GB2022, doi:10.1029/2010GB003862, 2011.

Schubert, C. J. and Calvert, S. E.: Nitrogen and carbon isotopic composition of marine and terrestrial organic matter in Arctic Ocean sediments: Deep-Sea Res. Pt. I, 48, 789-810, 2001.

Semiletov, I. P.: Destruction of the coastal permafrost ground as an important factor in biogeochemistry of the Arctic Shelf waters, Trans. (Doklady) Russian Acad. Sci., 368, 679-682, 1999 (translated into English).

Semiletov, I. and Gustafsson, Ö.: East Siberian Shelf Study Alleviates Scarcity of Observations, Eos, Trans. Am. Geophys. Union, 90, 145-146, 2009.

Semiletov, I., Dudarev, O., Luchin, V., Charkin, A., Shin, K. H., and Tanaka, N.: The East Siberian Sea as a transition zone between Pacific-derived waters and Arctic shelf waters, Geophys. Res. Lett., 32, L10614, doi:10.1029/2005GL022490, 2005.

Semiletov, I. P., Pipko, I. I., Shakhova, N. E., Dudarev, O. V., Pugach, S. P., Charkin, A. N., Mcroy, C. P., Kosmach, D., and Gustafsson, Ö.: Carbon transport by the Lena River from its headwaters to the Arctic Ocean, with emphasis on fluvial input of terrestrial particulate organic carbon vs. carbon transport by coastal erosion, Biogeosciences, 8, 2407-2426, doi:10.5194/bg8-2407-2011, 2011.

Semiletov, I. P., Shakhova, N. E., Sergienko, V. I., Pipko, I. I., and Dudarev, O. V: On carbon transport and fate in the East Siberian Arctic land-shelf-atmosphere system, Environ. Res. Lett., 7, 015201, doi:10.1088/1748-9326/7/1/015201, 2012.

Semiletov, I. P., Shakhova, N. E., Pipko, I. I., Pugach, S. P., Charkin, A. N., Dudarev, O. V., Kosmach, D. A., and Nishino, S.: Spacetime dynamics of carbon and environmental parameters related to carbon dioxide emissions in the Buor-Khaya Bay and adjacent part of the Laptev Sea, Biogeosciences, 10, 5977-5996, doi:10.5194/bg-10-5977-2013, 2013.

Semiletov, I., Pipko, I., Gustafsson, Ö., Anderson, L. G., Sergienko, V., Pugach, S., Dudarev, O., Charkin, A., Gukov, A., Bröder, L., Andersson, A., Spivak, E., and Shakhova, N.: Acidification of East Siberian Arctic Shelf waters through addition of freshwater and terrestrial carbon, Nat. Geosci., 9, 361-365, 2016.

Shakhova, N., Semiletov, I., Sergienko, V., Lobkovsky, L., Yusupov, V., Salyuk, A., Salomatin, A., Chernykh, D., Kosmach, D., Panteleev, G., Nicolsky, D., Samarkin, V., Joye, S., Charkin, A., Dudarev, O., Meluzov, A., and Gustafsson, O.: The East Siberian Arctic Shelf: towards further assessment of permafrost-related methane fluxes and role of sea ice, Philos. T. R. Soc. A, 373, 0451, doi:10.1098/rsta.2014.0451, 2015.

Stein, R. and Fahl, K.: Holocene accumulation of organic carbon at the Laptev Sea continental margin (Arctic Ocean): sources, pathways, and sinks, Geo-Mar. Lett., 20, 27-36, 2000.

Stein, R. and Fahl, K.: The Laptev Sea: Distribution, Sources, Variability and Burial of Organic Carbon, in: The Organic Carbon Cycle in the Arctic Ocean, edited by: Stein, R. and Macdonald, R. W., 213-236, 2004.

Stein, R. and Macdonald, R. W. (Eds.): The organic carbon cycle in the Arctic Ocean, Springer Verlag, 2004.
Stuvier, M. and Polach, H. A.: Reporting of ${ }^{14} \mathrm{C}$ Data, Radiocarbon, 19, 355-363, 1977.

Syvitski, J. P. M.: Sediment discharge variability in Arctic rivers: Implications for a warmer future, Polar Res., 21, 323-330, 2002.

Tarnocai, C., Canadell, J. G., Schuur, E. A. G., Kuhry, P., Mazhitova, G., and Zimov, S.: Soil organic carbon pools in the northern circumpolar permafrost region, Global Biogeochem. Cy., 23, GB2025, doi:10.1029/2008GB003327, 2009.

Tesi, T., Semiletov, I., Hugelius, G., Dudarev, O., Kuhry, P., and Gustafsson, Ö.: Composition and fate of terrigenous organic matter along the Arctic land-ocean continuum in East Siberia: Insights from biomarkers and carbon isotopes, Geochim. Cosmochim. Acta, 133, 235-256, 2014.

Tesi, T., Semiletov, I., Dudarev, O., Andersson, A., and Gustafsson, Ö.: Matrix association effects on hydrodynamic sorting and degradation of terrestrial organic matter during cross-shelf transport in the Laptev and East Siberian shelf seas, J. Geophys. Res.Biogeo., 121, 731-752, 2016.

van Dongen, B. E., Semiletov, I., Weijers, J. W. H., and Gustafsson, Ö.: Contrasting lipid biomarker composition of terrestial organic matter exported from across the Eurasian Arctic by the five great Russian Arctic rivers, Global Biogeochem. Cy., 22, GB1027, doi:10.1029/2007GB002974, 2008a.

van Dongen, B. E., Zencak, Z., and Gustafsson, Ö.: Differential transport and degradation of bulk organic carbon and specific terrestrial biomarkers in the surface waters of a sub-arctic brackish bay mixing zone, Mar. Chem., 112, 203-214, 2008b.

Vonk, J. E. and Gustafsson, Ö.: Permafrost-carbon complexities, Nat. Geosci., 6, 675-676, 2013.

Vonk, J. E., Sánchez-García, L., Semiletov, I., Dudarev, O., Eglinton, T., Andersson, A., and Gustafsson, O.: Molecular and radiocarbon constraints on sources and degradation of terrestrial organic carbon along the Kolyma paleoriver transect, East Siberian Sea, Biogeosciences, 7, 3153-3166, doi:10.5194/bg-73153-2010, 2010.

Vonk, J. E., Sánchez-García, L., van Dongen, B. E., Alling, V., Kosmach, D., Charkin, A., Semiletov, I. P., Dudarev, O. V., Shakhova, N., Roos, P., Eglinton, T. I., Andersson, A., and Gustafsson, Ö.: Activation of old carbon by erosion of coastal and subsea permafrost in Arctic Siberia, Nature, 489, 137-140, 2012.

Vonk, J. E., Semiletov, I. P., Dudarev, O. V., Eglinton, T. I., Andersson, A., Shakhova, N., Charkin, A., Heim, B., and Gustafsson, Ö.: Preferential burial of permafrost-derived organic carbon in Siberian-Arctic shelf waters, J. Geophys. Res.-Oceans, 119, 8410-8421, 2014.

Wegner, C., Hölemann, J. A., Dmitrenko, I., Kirillov, S., and Kassens, H.: Seasonal variations in Arctic sediment dynamics Evidence from 1-year records in the Laptev Sea (Siberian Arctic), Global Planet. Change, 48, 126-140, 2005.

Wegner, C., Bauch, D., Hölemann, J. A., Janout, M. A., Heim, B., Novikhin, A., Kassens, H., and Timokhov, L.: Interannual variability of surface and bottom sediment transport on the Laptev Sea shelf during summer, Biogeosciences, 10, 11171129, doi:10.5194/bg-10-1117-2013, 2013.

Weingartner, T. J., Danielson, S., Sasaki, Y., Pavlov, V., and Kulakov, M.: The Siberian Coastal Current: A wind- and buoyancyforced Arctic coastal current, J. Geophys. Res., 104, 29697, doi:10.1029/1999JC900161, 1999. 
Wiesenberg, G. L. B., Schwark, L., and Schmidt, M. W. I.: Improved automated extraction and separation procedure for soil lipid analyses, Eur. J. Soil Sci., 55, 349-356, 2004.

Winterfeld, M., Goñi, M. A., Just, J., Hefter, J., and Mollenhauer, G.: Characterization of particulate organic matter in the Lena River Delta and adjacent nearshore zone, NE Siberia - Part 2: Lignin-derived phenol compositions, Biogeosciences, 12, 22612283, doi:10.5194/bgd-11-14359-2014, 2015a.

Winterfeld, M., Laepple, T., and Mollenhauer, G.: Characterization of particulate organic matter in the Lena River delta and adjacent nearshore zone, NE Siberia - Part I: Radiocarbon inventories, Biogeosciences, 12, 3769-3788, doi:10.5194/bg-12-3769-2015, 2015 b.
Yunker, M. B., Macdonald, R. W., Cretney, W. J., Fowler, B. R., Mclaughlin, F. A., and Bay, R. R. B.: Alkane, terpene, and polycyclic aromatic hydrocarbon geochemistry of the Mackenzie River and Mackenzie shelf, Riverine contributions to Beaufort Sea coastal sediment, 57, 3041-3061, 1993.

Yunker, M. B., Macdonald, R. W., Veltkamp, D. J., and Cretney, W. J.: Terrestrial and marine biomarkers in a seasonally ice-covered Arctic estuary - integration of multivariate and biomarker approaches, Mar. Chem., 49, 1-50, 1995.

Yunker, M. B., Belicka, L. L., Harvey, H. R., and Macdonald, R. W.: Tracing the inputs and fate of marine and terrigenous organic matter in Arctic Ocean sediments: A multivariate analysis of lipid biomarkers, Deep-Sea Res. Pt. II, 52, 3478-3508, 2005. 